\title{
MANIPULAÇÃO E PERSUASÃO ATRAVÉS DA PROPAGANDA: O DISCURSO POLÍTICO INSERIDO NO CIBERESPAÇO
}

\author{
Igor Andrei Coelho Mafaldo ${ }^{1}$, Ana Luiza Coiro Moraes ${ }^{2}$ \\ ${ }^{1}$ Publicitário - Centro Universitário Franciscano - UNIFRA, Santa Maria/RS \\ igormafaldo@hotmail.com \\ ${ }^{2}$ Profa. Dra. - Docente do Centro Universitário Franciscano - UNIFRA, Santa Maria/RS \\ anacoiro@gmail.com
}

\section{RESUMO}

O presente estudo dispõe-se a refletir sobre as relações entre a atual propaganda política e a propaganda nazista, baseada esta última nos princípios propagandísticos criados por Joseph Goebbels, aliados a técnicas e meios de comunicação em massa e adotados como referência no campo da comunicação social. Neste sentido, partindo destes princípios propagandísticos, foram consideradas neste trabalho as estratégias implantadas na propaganda política nazista, bem como os discursos políticos dos candidatos a presidência do Brasil José Serra e Dilma Rousseff inseridos no ciberespaço. Portanto, objetiva-se neste estudo reconhecer os princípios de persuasão persistentes e aplicados na política atual, centrando na comunicação veiculada na internet, um dos meios de comunicação mais dominantes no mundo.

Palavras-chave: Propaganda. Comunicação. Política. Persuasão. Ciberespaço.

\begin{abstract}
The present study intents to reflect on the relations between the current political advertising and Nazi advertising, this last one based upon Goebbels' principles of propaganda, associated to mass media techniques and adopted by reference to media and news. In this sense, through these basic advertisement principles, this paper considered the strategies implemented in Nazi advertising, such as the political discourse engaged in by the candidates for president of Brazil José Serra and Dilma Rousseff, inserted into cyberspace. Thus, this study aims to recognize persistent principles of persuasion in current policy, focusing on communication transmitted on the Internet, one of the most mainstream media in the world.
\end{abstract}

Keywords: Advertisement. Communication. Politics. Persuasion. Cyberspace.

\section{INTRODUÇÃO}

O processo de aplicação de uma ideologia na mente das pessoas é uma estratégia conceituada pela propaganda. A palavra "propaganda", de origem latina, remete ao sentido da necessidade de se disseminar, difundir e alastrar alguma ideologia. De acordo com Sant'Anna (2002, p.79), "aquilo que precisa ser espalhado".

No início do século XX a propaganda foi utilizada pelos nazistas e constituiu-se em um importante instrumento responsável pela elevação e desenvolvimento do III Reich alemão. A 


\section{Monografias Ambientais}

REMOA

(Revista Eletrônica do Curso de Especialização em Educação Ambiental da UFSM)

ascensão e os ideais nazistas obtiveram êxito, dentre outros fatores, de natureza social, política e econômica, em virtude de uma campanha de propaganda integrada e estruturada estrategicamente.

Durante a carreira de Adolf Hitler, foi de suma importância a utilização dessa ferramenta para disseminar a sua ideologia política na Europa e no mundo.

Martins (2002) indica Joseph Goebbels como o principal responsável pelo desenvolvimento de uma lembrança do indiscutível episódio temporal, chamado Adolf Hitler. Isso porque foi juntamente com Joseph Goebbels, seu ministro da propaganda, que Hitler pode tirar proveito da utilização da propaganda. "É enorme a contribuição de Hitler e Goebbels à propaganda moderna, eles não a inventaram, mas a transformaram" (DOMENACH, 1955, p.46). Aliás, essa contribuição deu o viés sobre às técnicas de controle da opinião pública, conceituando assim a propaganda moderna.

Segundo Martins (2002, p.37) "Goebbels foi um inovador na comunicação de massa". Ou seja, em seu entendimento, através da propaganda dirigida às massas, Goebbels elevou de uma forma estratégica e tática a Alemanha, conseguindo unir sob o ideal nazista uma nação que estava à beira de um colapso.

Trata-se de um sistema de persuasão complexo de técnicas e meios de comunicação em massa que ajudaram a desenvolver a propaganda política moderna.

Pode-se dizer que Hitler foi inovador em sua propaganda. Não porque novas técnicas tivessem sido inventadas pelo nacional-socialismo, mas o que faz a sua propaganda tão eficaz são principalmente as combinações de elementos coletados de várias fontes, como teatro, ópera, propaganda política e dos meios de comunicação de massa que acabavam de nascer nos anos 20 (DIEHL, 1996, p.41).

Desta forma, lançando mão desses novos meios de comunicação que surgiam nos anos 20, o ministro da propaganda Joseph Goebbels foi o teórico criador de "leis", organizando sua cartilha sob princípios de dominação pela propaganda.

A propaganda nazista firmava seus discursos políticos nos diversos meios de comunicação, no entanto, "foi sobre o rádio que o regime nazista centralizou seu maior interesse" (PEROSA, 1995, p.26).

A propaganda política constituiu-se em um dos fenômenos marcantes da primeira metade do século XX. Diante da Alemanha derrotada na primeira guerra mundial, Adolf Hitler conseguiu reerguer uma nação utilizando uma propaganda integrada em torno de sua ideologia política. Ou seja, uma campanha constituída de um conjunto de técnicas e ferramentas elaboradas para a manipulação e persuasão de uma nação inteira.

Pode-se até dizer que, sem elas [técnicas de manipulação e persuasão pela propaganda] os grandes acontecimentos da nossa época: a revolução comunista e o fascismo, não seriam sequer concebíveis. Mussolini, Hitler e Lênin marcaram a história contemporânea com uso intensivo e cientifico da propaganda (SANT'ANNA, 1998, p.45).

Ainda, Hitler utilizou mídias alternativas como a cinegrafia, desde o seu surgimento, os eventos, o rádio, os desfiles das tropas, o uso da redação em cartazes e discursos persuasivamente elaborados. Todas essas técnicas estruturadas dentro de uma campanha totalmente integrada de modo a persuadir e manipular a população alemã. 


\section{Monografias Ambientais}

REMOA

(Revista Eletrônica do Curso de Especialização em Educação Ambiental da UFSM)

Assim, a disseminação de uma propaganda ideológica histórica, como a nazista, aliada à utilização de técnicas e meios de comunicação em massa, juntamente com os princípios propagandísticos de Joseph Goebbels, servem de referência ao campo da comunicação social.

E mais, sem tal feito histórico, talvez não houvesse interesse científico na propaganda como campo de ensino e tampouco estaria inserida na área de ciências sociais.

Seguindo na mesma linha, percebe-se que os métodos de se fazer propaganda política ao estilo Goebbels se perpetuam até hoje, com a diferença de existirem novos meios de comunicação como o ciberespaço, por exemplo.

Por isso, é possível relacionar as leis e princípios de dominação pela propaganda política daquela época nos modos utilizados por candidatos atuais de governo. No nosso caso ao governo do Brasil na eleição de 2010.

Assim como os meios de comunicação rádio e cinema foram largamente utilizados na propaganda nazista, este estudo recorre ao novo meio de comunicação que surge no ciberespaço, a internet, para verificar se apesar da diferença entre sua veiculação - áudio, vídeo e internet persistem semelhanças no discurso político.

Isso se contextualiza através da convergência digital midiática, termo que surgiu com o aparecimento de novos meios de informação e comunicação. Paula, André e Tavares (2009) colocam que se está numa era de mídias em todos os lugares, na qual há misturas de meios antigos com meios emergentes. Porém, de acordo com os autores, os velhos meios de comunicação (jornal, rádio, cinema) não estão sendo substituídos: suas funções e status estão, sim, sendo transformados pela introdução de novas tecnologias, como na internet.

Desta forma, a convergência pode ser vista como uma afluência de mídias que implica uma transformação tanto na forma de produzir quanto na forma de consumir os meios de comunicação.

Atualmente a internet é um dos meios de comunicação dominantes no mundo, assim como o rádio e o cinema já tiveram a sua era. (A propaganda política dos candidatos ao governo do Brasil poderia ser baseada nas mesmas leis e regras criadas por Goebbels?).

Em um mundo digital onde o partido político, seja qual for, consegue falar diretamente com o eleitor, e não há outros interlocutores que possam distorcer a mensagem do candidato, editá-la ou inclusive reduzi-la, a internet é um importante instrumento.

Além do mais, a internet proporciona uma maior interação com os candidatos, que por sua vez podem recorrer a qualquer tipo de propaganda política, como por exemplo, o discurso e propaganda política sob as leis e princípios de dominação pela propaganda, criadas por Joseph Goebbels.

Buscam-se estes princípios na propaganda de era pós-moderna, aqui representada pelos novos meios de comunicação configurados no ciberespaço.

Neste sentido, relacionando a propaganda política nazista com a propaganda atual do século XXI, a investigação deste estudo responde a seguinte questão: é possível reconhecer traços dos princípios de dominação pela propaganda de Joseph Goebbels inseridos nos discursos dos dois principais candidatos a Presidência da República do Brasil, Dilma Rousseff e José Serra, no meio internet?

Levando-se em consideração as estratégias adotadas na propaganda política nazista, este trabalho tem o objetivo de identificar e verificar se os princípios de propaganda criados por Joseph Goebbels no século XX, persistem na política atual, centrando na comunicação veiculada no meio internet dos dois candidatos a presidência do Brasil, José Serra e Dilma Rousseff. 


\section{Monografias Ambientais}

REMOA

(Revista Eletrônica do Curso de Especialização em Educação Ambiental da UFSM)

Objetiva-se neste estudo, também descrever o uso dos princípios de propaganda e persuasão de Joseph Goebbels, localizar os ambientes ocupados por Dilma e Serra no ciberespaço e relacionar as leis de propaganda nazistas com os discursos propagandísticos dos dois candidatos e verificar se as leis persistem no discurso político pós-moderno do ciberespaço e se assemelham as leis de propaganda criadas por Joseph Goebbels.

\section{REFERENCIAL TEÓRICO}

\section{A PROPAGANDA POLÍTICA}

A palavra "política" vem do termo grego "pólis" que significa cidade-estado, e que segundo Aristóteles ${ }^{1}$ citado por Hourdakis (2001), tem como tarefa mais importante buscar a melhor forma de governo e instituições que garantam satisfação coletiva.

A idéia que fazemos de democracia vem-nos da Grécia, por intermédio de Aristóteles e sua classificação das formas de governo. Ela é, segundo conceito clássico, o governo do povo pelo povo, o regime político em que o poder reside na massa dos indivíduos e é por eles exercido, diretamente ou por meio de representantes eleitos. (AZAMBUJA, 1999, p.16).

Deve-se ressaltar que a idéia de democracia da Grécia, diferente da idéia de hoje, era válida apenas para os cidadãos, isto é, os homens livres e nascidos em solo grego e não para os escravos e nem para as mulheres.

A propaganda política em toda a sua essência é voltada a objetivos ideológicos, como afirma Domenach (1955), este tipo de propaganda política de tendência totalitária, é que decorre da fusão da ideologia com a política.

Segundo Coneglian (2010) o gênero "propaganda política" compreende toda e qualquer propaganda que gire em torno da "polis", ou da política, compreendida essa em seu sentido mais abrangente, de relações do cidadão com sua própria cidadania.

Em uma forma de governo democrática como no Brasil, a propaganda política é vista como um elemento importante. Segundo Azambuja (1999) a propaganda política visa a valorizar e exaltar um candidato, um partido, um regime, um governo, e quase menosprezar, criticar e ridicularizar o adversário. Exagera ou inventa as qualidades daqueles e silencia ou nega as qualidades deste, se porventura as tem.

Para Manhanelli (2004) a propaganda política é organizada para influenciar a opinião pública. Ela apareceu antes do marketing. Exemplo disso foi o que aconteceu há sessenta anos, quando os nazistas criaram um super-ministério só para fazer propaganda do regime.

De acordo com Oliveira (1996), a propaganda atua no sentido de influenciar os grupos sociais a partir de técnicas de persuasão. Desde os primórdios, este princípio fundamental é aplicado na comunicação social.

Portanto, ao afirmar que os recursos a serem manipulados são estabelecidos pelo processo comunicativo, a persuasão fundamenta o trabalho de exploração psicológica que deve corresponder aos interesses dos indivíduos, bem como os comportamentos resultantes da ação devem beneficiar o patrocinador.

\footnotetext{
${ }^{1}$ Segundo Hourdakis (2001, p.9) Aristóteles (Estagira, Calcídica, 384 a.C. - 322 a.C.) nada ignorou de tudo o que se conhecia em sua época. Foi pesquisador, filósofo e fundador de numerosas ciências.
} 


\title{
Monografias Ambientais
}

REMOA

(Revista Eletrônica do Curso de Especialização em Educação Ambiental da UFSM)

Assim, a propaganda é ditada principalmente pela persuasão manipulativa, na qual o interesse de conduta está ligado aos objetivos do patrocinador.

\section{O DISCURSO POLÍTICO}

A simples reflexão sobre o significado de discurso já remete a textos escritos e/ou falados, mas, também, remete à argumentação, oratória e retórica.

Charaudeau (2008) caracteriza a argumentação como aquela que se dirige à capacidade de refletir e compreender do interlocutor. O sujeito que argumenta passa pela expressão de uma convicção e de uma explicação através da oratória e da retórica, tentando persuadir o interlocutor a modificar suas conviç̧ões e crenças.

Portanto, argumentação, oratória e retórica são resultados de uma combinação entre diferentes componentes que dependem de uma situação que tem finalidade persuasiva.

\begin{abstract}
O discurso político é um discurso de busca do poder. No entanto, deve ele afirmar um querer-ser e um saber-fazer do enunciador, ou seja, o político que busca o poder deve afirmar seu desejo de ser investido do poder e sua capacidade (saber) de satisfazer às necessidades e reivindicações dos atores sociais. (FIORIN, 1988, p.144).
\end{abstract}

Essa busca de poder determina o querer-ser do enunciador e parte para o saber-fazer que relaciona a adequação do discurso político para determinado público-alvo a quem o enunciador quer atingir.

Segundo Gaudêncio (2004), deve-se considerar que o princípio-mor do discurso político é o de provocar uma reação emotiva de interesse. Para tanto, há de despertar atenção. E a intensidade da atenção vai depender do teor das mensagens, do interesse efetivo que a mensagem provoca no ouvinte e em seu psicológico.

O discurso político também deve ser claro, objetivo, acessível e interessante, mas a isto deve-se acrescer o fato de que é o discurso que vai dar vida e movimentação aos temas, despertando e manipulado as emoções do público ouvinte. (KUNTZ, 2004, p.65).

Pode-se assim dizer que o discurso político é um texto argumentativo, persuasivo e emotivo, pelo bem comum, sustentado por pontos de vista do emissor ou de enunciadores que o reproduzem, e por informações compartilhadas que exprimem valores sociais, políticos, religiosos e outros.

Para Gomes (2004) essas informações transmitidas, pelo candidato ou pelo partido, ao eleitor, através dos meios de comunicação de massa, só ajudam a cumprir o objetivo maior da comunicação, que é exercer uma influência sobre o cidadão, para que este assuma uma determinada posição frente à mensagem que recebe.

\section{A PROPAGANDA NAZISTA}

Os nazistas, juntamente com a educação, o trabalho e os movimentos sociais, tinham a propaganda política como uma das principais ferramentas para atingir seus objetivos.

Segundo Couto (2007) o sucesso da propaganda nazista concretizou-se devido à manipulação da verdade por meio desta. 


\section{Monografias Ambientais}

REMOA

(Revista Eletrônica do Curso de Especialização em Educação Ambiental da UFSM)

Este tipo de propaganda tinha como foco atingir emocionalmente grandes massas, criando no receptor uma ligação persuasiva com a mensagem emitida.

Diehl (1996) compartilha do ponto de vista de que era preciso que se apresentasse um mundo maniqueísta, de fácil compreensão e de idéias simplistas, pois a massa deveria ser conquistada por "seus sentimentos" e não por sua capacidade de análise. Quanto mais simplista e radical a propaganda, mais seguros os resultados obtidos com ela.

Um dos princípios da propaganda nazista era "toda propaganda deve ser popular e estabelecer o seu nível espiritual de acordo com a capacidade de compreensão do mais ignorante dentre aqueles a quem ela pretende se dirigir" (HITLER, 1962[1929], p.192).

Hitler, ao dizer que "A arte da propaganda reside justamente na compreensão da mentalidade e dos sentimentos da grande massa." (HITLER, 1962[1929], p.54), sob o ponto de vista e Diehl (1996), estava "abrindo o jogo", explicando sua estratégia de comunicação.

Hitler considerava abertamente a manipulação das massas como instrumento político. Esta é a grande novidade e força do nacional-socialismo: a explicitação de um método para o controle da massa por meio da propaganda. (DIEHL, 1996, p.48).

De acordo com Bortolucce (2008), a implantação da propaganda, assim como a apresentação visual, foram as primeiras providências tomadas pelo partido nazista.

Estabeleceu-se, então um forte e sólido sistema de propaganda dirigido às massas, caracterizado pela simplicidade e concentração no menor número possível de elementos. Assim, as idéias nacional-socialistas repetiam-se de várias maneiras e inúmeras vezes.

O partido Nazista assumiu gradualmente o controle do sistema de comunicação, dos partidos, dos sindicatos e outras organizações. Mas é Joseph Goebbels, ministro da informação e Propaganda do governo, empossado em março de 1933, que coube a tarefa de organizar todos os setores usados como instrumento de propaganda: os meios de comunicação. (PEROSA, 1995, p. 26).

Todos os meios de comunicação eram válidos no uso da propaganda nazista, em especial o rádio.

O poderoso idealizador e chefe da propaganda nazista, Joseph Goebbels, em 1933, ao inaugurar uma exposição sobre radiofonia em Berlim, declarou que no século o rádio deveria assumir o mesmo papel que a imprensa escrita desempenhara no século anterior. (GOLIN e ABREU, 2006, p.73).

O rádio era uma arma fundamental não apenas na propaganda interna do regime nazista, mas também na propagação das idéias nazistas além das fronteiras alemãs. (SOUZA, 2004, p.55).

Como Joseph Goebbels, ministro da propaganda política de Hitler, diria posteriormente: "Não teria sido possível para nós tomar o poder ou usá-lo da maneira que usamos sem o rádio. (...) O rádio é o intermediário mais influente e importante entre o movimento espiritual e a nação, entre a idéia e o povo". (GORE, 2007, p.84).

O meio rádio somente "fala", então detém maior atenção do seu ouvinte, e possui uma grande vantagem sobre uma parcela da população que antes não era impactada pelos veículos jornalísticos impressos; a faixa da população analfabeta. 


\section{Monografias Ambientais}

REMOA

(Revista Eletrônica do Curso de Especialização em Educação Ambiental da UFSM)

No nazismo o rádio era o principal instrumento de difusão da palavra e reforçava todo o discurso impresso nos cartazes e textos impressos. Conforme Couto (2007), o controle sobre os meios de comunicação era intenso.

Os radialistas e jornalistas, por exemplo, precisavam necessariamente obter aprovação prévia para que seus trabalhos fossem finalmente divulgados para o público.

No cinema, pode-se destacar a afirmação de Rees (1995), que relata o reconhecimento de Goebbels acerca do poder fundamental dos filmes na propaganda como um importante veículo de comunicação. Segundo ele, a inteligência, a imaginação e o consciente dos indivíduos são influenciados por transmissões de rádio e notícias de jornais, enquanto o inconsciente movimenta forças primárias que o levam a prosseguir além da consciência. Os filmes, por sua vez, não exercem influência no intelecto do homem, e sim em suas verdadeiras forças primárias, trabalhando-as intensamente.

Desta forma, é possível criar sentimentos que, uma vez implantados, são mais difíceis de remover do que uma opinião criada através da razão.

\section{JOSEPH GOEBBELS E OS PRINCÍPIOS DA PROPAGANDA}

Joseph Goebbels desenvolveu técnicas de convencimento individual e coletivo para conhecer ansiedades e necessidades psicológicas da população e satisfazer tudo isso, concedendo em troca o produto Führer. Tais técnicas, de acordo com Domenach (1955) são:

1) Simplificação ou do Inimigo único: adotar um única idéia, um único símbolo. Individualizar o adversário em um único inimigo.

2) Método do Contágio: reunir diversos adversários em uma só categoria, em uma soma individualizada.

3) Transposição: carregar sobre os adversários seus próprios erros e defeitos, respondendo ataque com ataque. Se não podes negar as más notícias, invente outras que as distraiam.

4) Exagerar e desfigurar: converter qualquer história, por menos que seja, em ameaça grave.

5) Vulgarização: toda propaganda deve ser popular, adaptando seu nível ao menos instruído dos indivíduos aos quais se dirija. Quanto maior a massa a convencer, menor o esforço mental a realizar. A capacidade receptiva das massas é limitada, sua compreensão é escassa e tem grande facilidade para esquecer.

6) Orquestração: a propaganda deve limitar-se a um número pequeno de idéias e repeti-las incansavelmente, apresentando-as uma e outra vez, de diferentes perspectivas, mas sempre convergindo para o mesmo conceito, sem fissuras nem dúvidas.

7) Renovação: emitir, sempre, informações e argumentos novos a um ritmo tal que quando o adversário responda, o público já esteja interessado em outra coisa.

8) Verossimilhança: construir argumentos a partir de fontes diversas, através de informações fragmentárias.

9) Silenciação: encobrir as questões sobre as quais não tenha argumentos e dissimular as notícias que favorecem o adversário, contraprogramando com a ajuda dos meios de comunicação afins.

10) Transfusão: a propaganda sempre opera a partir de um substrato preexistente, seja uma mitologia nacional, ou um complexo de ódios e preconceitos tradicionais. Trate de difundir argumentos que possam arrigar-se em atitudes primitivas.

11) Unanimidade: convencer a muita gente de que se pensa "como todo mundo", criando uma (falsa) impressão de unanimidade. 


\section{Monografias Ambientais}

REMOA

(Revista Eletrônica do Curso de Especialização em Educação Ambiental da UFSM)

\section{O MARKETING POLÍTICO NO CIBERESPAÇO}

Na propaganda política "o Marketing Político é um esforço planejado para se cultivar a atenção, o interesse e a preferência de um mercado de eleitores, é o caminho seguro para o sucesso de quem deseja vencer na política" (REGO, 1985, p.23).

Para Queiroz (2006), o marketing político não é restrito a um meio de comunicação; além de uma imensa rede de comunicações, abrange ainda a pesquisa, discursos, articulação social e política, assim como a mobilização de massas. O marketing político é um conjunto de maneiras e meios de operar a política, que por sua vez muda o seu modo de operar no decorrer do tempo e do espaço.

Atualmente, grande parte dos avanços da tecnologia representa-se de forma mais clara no desenvolvimento evolutivo dos meios de comunicação.

Dentre os meios de comunicação mais atuais pode-se citar a internet, que pode ser definida, segundo Saad (2003, p.22), como "uma rede mundial de computadores interconectados que possibilita a troca de mensagens, dados e arquivos entre os usuários."

A internet, uma ferramenta estratégica de comunicação, agrega um ambiente de comunicação digital dentro do chamado ciberespaço. O termo "cyberspace ${ }^{2 "}$ contextualiza-se em um mundo virtual onde se realizam trocas de informações entre as pessoas, e que, de acordo com Silva (2004, p.17) "consiste em uma região abstrata invisível que permite a circulação de informações na forma de imagens, sons, textos etc."

Novas ferramentas sociais inseridas na internet proporcionam novos instrumentos de comunicação social.

Segundo Recuero (2009), a comunicação mediada pelo computador, mais do que permitir aos indivíduos comunicar-se, amplificou a capacidade de conexão, permitindo que redes fossem criadas e expressas nesses espaços: as redes sociais mediadas pelo computador.

As eleições norte-americanas de 2008 mostraram que políticos e eleitores podem interagir de maneira diferente, pela primeira vez as mídias digitais foram usadas em massa, de diversas formas, na tentativa de conquistar o voto.

O marketing político desempenhado pela equipe de Barack Obama em 2008 foi um exemplo mundial e alcançou resultados reconhecidos e expressivos, sagrando o primeiro presidente negro dos EUA.

A campanha arrecadou 750 milhões de dólares, sendo que $67 \%$ proveniente da internet. A equipe possui mais de 1800 vídeos cadastrados em seu canal do youtube, com 23 milhões de visitas; e no twitter Barack Obama tem 2.260.689 seguidores, mais de 500 grupos no facebook e quase 7 milhões de amigos. Ao todo, Barack Obama estava presente em mais de 16 redes sociais na web.

O foco principal da estratégia de marketing realizada pela equipe de Obama foi a internet, que conseguiu trazer as pessoas do mundo online em redes sociais e que na essência da cibercultura é um universo sem totalidade, ou seja, se alastra e emerge num universo cibernético.

Lévy (1999, p.111) diz que a cada minuto que passa, novas pessoas passam a acessar a Internet, novos computadores são interconectados e novas informações são injetadas na rede; e

\footnotetext{
${ }^{2}$ No que se refere a noção de ciberespaço, a terminologia vem de cyber, da "teoria da cibernética" desenvolvida no final da Segunda Guerra pelo matemático Norbert Wiener. Mais recentemente (1984), o termo "cyberspace" foi utilizado pelo escritor de ficção científica Willian Gibson em "Neuromancer". Para Gibson (1984), o ciberespaço é um espaço não físico ou territorial, que se compõe de um conjunto de redes de computadores através das quais todas informações (sob variadas formas) circulam. A partir de Gibson este termo popularizou-se.
} 


\section{Monografias Ambientais}

REMOA

(Revista Eletrônica do Curso de Especialização em Educação Ambiental da UFSM)

ainda ressalta que quanto mais o ciberespaço se amplia, mais ele se torna "universal". Pode-se ressaltar então que o marketing político de alguma forma adapta-se aos meios de comunicação atuais.

\section{A INTERNET COMO MEIO DE CONVERGÊNCIA MIDIÁTICA}

De acordo com Filho e Herschmann (2007), existe um consenso a respeito das possibilidades e limitações das primeiras mídias de massa, como o rádio e a televisão, e a influência destes meios de comunicação entre os indivíduos.

A internet é uma nova tecnologia e levanta novos questionamentos acerca destas características, pois desempenha um papel de convergência midiática e fornece conteúdos de formas variadas que podem ser acessados pelo público em diferentes situações cotidianas.

Segundo Cardoso (2007), existe uma articulação em rede de mídia e usos, através de diferentes tecnologias de comunicação e informação. Assim, a convergência tecnológica é marcada pela presença de jornais online, estações de rádio, assim como a televisão, cinema e músicas disponíveis na internet.

Por meio da recente introdução de tecnologias digitais na comunicação, novos conteúdos são feitos para existirem simultaneamente em múltiplas plataformas. Neste ambiente, a audiência pode se conectar a eles em diferentes situações e com variados graus de engajamento., As mídias se tornaram complementares umas às outras de forma a oferecer uma maior experiência do conteúdo à audiência. (Filho e Herschmann, 2007, p. 89).

Neto (2006) comenta a respeito da intensa evolução digital, afirmando ainda que "o mundo da comunicação será totalmente digital". Segundo o autor, a revolução da tecnologia, aliada à evolução do marketing resultaram em uma nova configuração da mídia, assim como novos hábitos e comportamentos.

Atualmente, o sistema digital integra intensamente todas as plataformas de comunicação da mídia moderna, por meio de acessos geograficamente ilimitados. Através da internet, a propaganda televisiva, assim como notícias de jornais e revistas, pode ser acessada, vista e ouvida.

A convergência das mídias, tão discutida e prognosticada na década passada, reúne numa mesma plataforma de comunicação diversas possibilidades de transmissão e já é uma realidade entre todos nós. (...) As disponibilidades comerciais dos satélites, os crescentes serviços online, as surpreendentes novidades introduzidas pela telecomunicação, entre outros, viabilizam novos planos de comunicação e já se apresentam eficazes no contato com determinados segmentos da população (NETO, 2006, p. 166).

Dizard Jr ET. AL. (1998) afirma que a convergência da mídia representa a união da mídia através de dos computadores e da digitalização em um sistema único, ou um conjunto de sistemas inter-relacionados. Deste modo, em uma sociedade democrática caracterizada pela valorização da escolha e variedade, a tecnologia disponibiliza muitas opções aos produtores e aos espectadores de mídia.

A nova cultura política - bem como a nova cultura popular - reflete o jogo de forças entre dois sistemas de mídia: um, de radiodifusão e comercial, e o outro, destinado a um público menor e alternativo. É mais provável que novas idéias e pontos de vista 


\section{Monografias Ambientais}

REMOA

(Revista Eletrônica do Curso de Especialização em Educação Ambiental da UFSM)

alternativos surjam no ambiente digital, mas a mídia vai monitorar esses canais, procurando conteúdos que possa cooptar e circular. Canais de mídia alternativos dependem de um quadro de referências comum, criado pelos intermediários tradicionais; a maioria dos conteúdos 'virais' mais bem-sucedidos da web faz críticas ou paródias da mídia comercial. A radiodifusão fornece a cultura comum, e a web oferece canais mais adaptados para a reação a essa cultura (JENKINS, 2008, p. 276).

No que se refere ao marketing político, a internet pode ser estrategicamente utilizada, acarretando em benefícios para a campanha. Desta forma, os sites dos candidatos podem revelar sua história, assim como suas propostas e posicionamentos. Ainda, os eleitores poderão utilizar blogs, redes sociais e mensagens instantâneas para promover seu candidato.

Além disso, a internet é um importante meio de divulgação de notícias e de influência política, pois além destas ferramentas também disponibiliza em sua rede propagandas e discursos políticos destinados às mídias em massa, como televisão, rádio, jornais e revistas, que podem ser acessados a qualquer momento.

\section{A PROPAGANDA DE SERRA E DILMA NA INTERNET}

De acordo com Castells (2003), espera-se que a internet atue como um instrumento ideal na promoção da democracia, pois ela permite um fácil acesso à informação política e, em princípio, possibilita aos cidadãos ter tanto conhecimento quanto o seu líder e todos os registros públicos poderiam ser disponibilizados online. Por canais interativos, o cidadão tem a possibilidade de solicitar informações, manifestar pontos de vista e solicitar respostas pessoais para quem os representa.

Para Cardoso (2006), atualmente os cidadãos não só desejam participar do ato de votar ou aprovar, mas também querem discutir. Portanto, o meio de difusão da palavra tornou-se eletrônico e a política de massas apela ao uso da internet, essencialmente interativa, e à política e massas.

O Brasil é um dos países que mais utilizam a internet em todo o mundo e as experiências desta mídia no marketing político já permitem verificar um diferencial positivo no uso para algumas das principais etapas de uma ação política bem-sucedida (ITEN e KOBAYASHI, 2002, p.188).

Como se viu na campanha de Barack Obama em 2008, o uso da internet foi fundamental no sucesso da campanha. Ele não venceu exclusivamente em razão da internet, mas sem ela não teria conseguido a eleição. José Serra e Dilma Rousseff possuem relações semelhantes em suas campanhas com a de Barack Obama, através de redes sociais, vídeos e sites no ciberespaço.

A apropriação da capacidade de interconexão por redes sociais de todos os tipos levou à formação de comunidades on-line que reinventaram a sociedade e, nesse processo, expandiram espetacularmente a interconexão de computadores, em seu alcance e em seus usos. (CASTELLS, 2003, p.53).

As redes sociais na internet ultrapassam a barreira do mundo off-line e online, isso modificou as formas de relacionamento entre pessoas e informação.

A interatividade digital é uma relação técnico-social e possibilita ao usuário interagir não só com o objeto, mas também com a informação. Com a web, a 


\section{Monografias Ambientais}

REMOA

(Revista Eletrônica do Curso de Especialização em Educação Ambiental da UFSM)

interação é de todos os usuários concomitantemente com todos os usuários. Esta relação evolui no sentido da superação das barreiras físicas entre os homens e máquinas, para um crescente interação do usuário com a informação (WACHOWICZ, 2006, p.54.)

Dentre os dois candidatos à Presidência do Brasil pode-se destacar o uso de twitters, orkuts, blogs e sites. Serra e Dilma conseguem falar diretamente com o eleitor.

A internet é um meio que permite a um partido político transmitir toda uma série de idéias diretamente ao eleitor, em especial quando as mensagens são postadas nas redes sociais.

Além do mais, a internet proporciona uma maior interação com os candidatos. Segundo Recuero (2009) o Twitter é estruturado com seguidores e pessoas a seguir, onde cada twitter pode escolher quem deseja seguir e ser seguido por outros. Há também a possibilidade de enviar mensagens em modo privado para outros usuários. Outro exemplo utilizado por Serra e Dilma é o Orkut.

Segundo o site Globo.com ${ }^{3}$ (2010), o Orkut continua sendo a rede social mais acessada pelos brasileiros, com os números divulgados em junho de 2010 pelo Ibope Nielsen Online. Com 26,9 milhões de visitantes únicos no mês de maio, a rede social do Google ainda tem larga vantagem sobre Facebook e Twitter, que aparecem empatados com 10,7 milhões.

O blog também é uma ferramenta utilizada por Dilma e Serra, e hoje em dia pela importância que adquiriu, e pelo grande número de pessoas que o acessa, uma grande troca de informações entre os internautas é assegurada.

Segundo Mercado (2008), o blog é uma publicação online ou que envolve a exposição pessoal na internet e caracteriza-se pela configuração cronológica inversa das entradas que ocorrem diariamente e buscam conexões, notícias e opiniões informais e subjetivas, de autoria individual na maioria das vezes.

Querido e Ene (2003) definem o blog como um diário em formato eletrônico e interativo, pois recebe comentários dos leitores. Pode ser criado rapidamente e gratuitamente por qualquer pessoa que possua acesso à internet. O blog é definido pelos arquivos, que comportam as entradas do blog, e os comentários.

As redes sociais são pessoas reunidas por questões de comportamento e afinidade, isso permite a segmentação de acordo com o perfil dos eleitores criando um canal de comunicação e interação inéditos.

Jenkins (2008) afirma que o bloguismo é uma forma de convergência alternativa. Neste sentido, a comunidade blogueira reúne notícias, informações e realiza debates desafiando suposições.

Desta forma, os blogueiros demonstram a impaciência com os canais tradicionais de informações, e disponibilizam na internet uma análise mais crítica dos acontecimentos.

Blogueiros não tem a pretensão de ser objetivos; são quase sempre simpatizantes, sem nenhum constrangimento; quase sempre lidam com boatos e insinuações (...) o bloguismo pode estar, em um aspecto, facilitando o fluxo de idéias pelo panorama da mídia; em outros aspectos, está assegurando um debate político cada vez mais agregador. (JENKINS, 2008, p.281).

\footnotetext{
${ }^{3}$ Disponivel em: <http://g1.globo.com/tecnologia/noticia/2010/06/orkut-segue-lider-no-brasil-twitter-e-facebook-empatam.html> Acesso em: 01 de Agosto de 2010.
} 


\section{Monografias Ambientais}

REMOA

(Revista Eletrônica do Curso de Especialização em Educação Ambiental da UFSM)

Quanto à propaganda política de Serra e Dilma, esta buscou a utilização dos diversos meios pelas campanhas dos dois candidatos, nos discursos de hoje através da convergência midiática possibilitada pela internet.

Ambos os candidatos criaram perfis em sites de relacionamento, como o Twitter e o Orkut, e implantaram blogs pessoais e sites oficiais com o uso também de vídeos postados para divulgar suas metas, propostas de governo, assim como notícias a respeito de suas campanhas políticas.

Estabeleceram-se, ainda, outros blogs ministrados por usuários da internet, defendendo o candidato de preferência da cada blogueiro, nos quais se verifica uma análise crítica dos fatos, assim como diversas acusações contra o candidato adversário.

\section{METODOLOGIA}

Para a realização deste estudo, alguns passos metodológicos foram seguidos. Verificou-se que a pesquisa é de natureza qualitativa, de cunho discursivo, tendo como foco as construções, aproximações, semelhanças e diferenças da propaganda política, em dois momentos e em dois meios.

Em primeiro lugar, a propaganda nazista, através dos princípios cunhados por Joseph Goebbels, utilizando os meios como: rádio, cinema e jornal. Em segundo lugar a propaganda de dois dos candidatos a presidentes da república do Brasil - Dilma e Serra - veiculada na internet, por meio dos blogs e páginas oficiais dos candidatos, e de redes sociais também analisadas sob os princípios de Joseph Goebbels.

Trata-se de um estudo de caso, e que possibilita uma análise da situação da propaganda política de Dilma e Serra bem como dos fatores que as influenciam ou são influenciados pelo meio internet.

Gil (2002) descreve um estudo de caso como sendo um estudo profundo e exaustivo de um ou poucos objetos, de maneira que permita seu amplo e detalhado conhecimento. Duarte e Barros (2005) afirmam que o estudo das peculiaridades, das diferenças, é o que torna este delineamento único, contribuindo para um melhor entendimento dos fenômenos sociais, organizacionais ou políticos.

O presente trabalho refere-se a um estudo de caso da propaganda no Brasil, no qual estão envolvidas algumas técnicas de pesquisas para analisá-lo. Um levantamento bibliográfico, com o objetivo de identificar informações bibliográficas a respeito do objeto de trabalho e utilizá-las como ferramentas de estudo.

De acordo com Michel (2005) é o momento da pesquisa que auxilia nos objetivos e levanta informações sobre o tema estudado.

Nesta etapa, foram coletadas referências sobre a propaganda nazista, bem como sobre a propaganda dos principais candidatos à Presidência da República e seus meios de divulgação através da internet. Essas fontes são encontradas por meio de livros, revistas e artigos publicados via Internet.

Ou seja, um levantamento documental de dados, que compreende a verificação de documentos com o objetivo de identificar e analisar o discurso político dos dois candidatos Dilma e Serra. 


\section{Monografias Ambientais}

REMOA

(Revista Eletrônica do Curso de Especialização em Educação Ambiental da UFSM)

Segundo Vergara (2003) a pesquisa documental tem por finalidade reunir, classificar e distribuir os documentos. Neste caso, são verificados sites de redes sociais, dos partidos dos políticos, assim como notícias e entrevistas veiculadas na internet.

Por fim, procurou-se a análise do conteúdo que, segundo as proposições de Bardin (2002), trata-se do desvendamento de significações de diferentes tipos de discursos. Isso se realiza a partir das informações bibliográficas e coletas de dados, pela pré-análise, exploração do material, e pela interpretação dos resultados obtidos, isto é, comparando os discursos políticos atuais com os princípios de Joseph Goebbels.

\section{RESULTADOS E DISCUSSÕES}

Analisam-se os discursos dos candidatos Dilma Rousseff e José Serra veiculados por diversos meios como blogs e websites, na internet, em relação às leis e princípios de dominação pela propaganda segundo Joseph Goebbels.

\section{SIMPLIFICAÇÃO OU DO INIMIGO ÚNICO}

Adotar uma única idéia, um único símbolo. Individualizar o adversário em um único inimigo. A própria essência da propaganda inclui a busca da simplificação de uma idéia base, definindo a argumentação que se desenvolverá, de forma mais clara possível, na direção do público alvo que se quer atingir.

A comunicação eficaz busca a simplificação da mensagem a ser transmitida, identificando os pontos principais e minimizando-os de maneira clara e objetiva.

\footnotetext{
Em todos os domínios, a propaganda logo se empenha na busca da simplificação. Trata-se de dividir a doutrina e a argumentação em alguns pontos, definindo-os o mais claramente possível. O propagandista tem a disposição uma escala inteira de fórmulas: manifestos, profissões de fé, programas, declarações, catecismos, os quais, em geral sob forma afirmativa, enunciam certo número de proposições em texto conciso e claro. (DOMINACH, 1955, p.68).
}

A simplificação de uma idéia relaciona-se com a criação de símbolos ou programas ideológicos, como a criação de programas de governos dos partidos PSDB e PT. Fernando Henrique Cardoso, conhecido como FHC, presidente eleito por duas vezes (1995 a 2002) pelo PSDB, durante seu governo criou uma rede de proteção social. "Meu governo vinha preparando e pondo em prática uma série de medidas de uma agenda social robusta que, posteriormente, veio a se chamar de "rede de proteção social". (CARDOSO, 2006, p. 494).

Essa rede de proteção social constituiu-se na união de diferentes programas de âmbito social que orientam essas alternativas em forma de assistência para a classe brasileira mais carente, determinada através de parâmetros de renda e constituição familiar. A Bolsa Escola, o Auxílio Gás e a Bolsa Alimentação são exemplos dos programas integrantes a rede de proteção social criada por FHC, que o candidato, José Serra do mesmo PSDB, em seu blog define da seguinte forma: 


\section{Monografias Ambientais}

REMOA

(Revista Eletrônica do Curso de Especialização em Educação Ambiental da UFSM)

reunidos pelo Bolsa Família, estiveram na origem deste programa. Nós vamos ampliar e melhorar o Bolsa Família. Mas vamos além. Vamos ampliar a rede de proteção social para cerca e 27 milhões de brasileiros que estão na base da pirâmide. Em português claro: vamos trabalhar com todas as nossas forças para acabar com a miséria absoluta no nosso País. Vamos lutar por isso. É possível fazer. (SERRA, 2010).

José Serra utiliza como um exemplo de simplificação de idéia única, durante sua campanha política veiculada na internet, a rede de proteção social e tem-se como adoção de uma idéia simplificada e resumida de diversos programas de âmbitos sociais, que se define em um plano de governo e tornando a idéia de forma clara para a população. É o que Serra contextualiza em um de seus blogs:

Vamos ampliar a rede de proteção social para cerca de 27 milhões de brasileiros que estão na base da pirâmide. Em português claro: vamos trabalhar com todas as nossas forças para acabar com a miséria absoluta no nosso País. Vamos lutar por isso. É possível fazer. (SERRA, 2010).

Em contrapartida, essa idéia de simplificação que rege uma campanha de propaganda política identifica-se também no Partido dos Trabalhadores, com o programa Fome Zero, criado para combater a fome, que gera a inclusão social, e para garantir alimentação aos brasileiros mais carentes.

No programa Fome Zero são organizadas idéias de forma a permitir a compreensão das estratégias discursivas adotadas pelo Partido dos Trabalhadores, na formação de uma identidade que se justifica na simplificação de uma idéia única.

O Fome Zero, principal programa social do governo, pretende erradicar a fome por meio de ações emergenciais e estruturais. As primeiras consistem na distribuição e cestas básicas e de $\mathrm{R} \$ 50,00$ mensais a famílias com renda per capita inferior a um salário mínimo. Já as ações estruturais pretendem estimular projetos de geração de renda, capazes de fazer com que as famílias beneficiadas pelo programa saiam da condição e pobreza. (FERREIRA, 2006, p.50).

Outra simplificação de idéia se apresenta no Programa de Aceleração do Crescimento PAC 2007-2010, lançado pelo governo federal em âmbito nacional no dia 22 de janeiro de 2007 no governo de Luiz Inácio Lula da Silva, presidente eleito de 2003 a 2010 e representante do partido dos trabalhadores. Um programa de expansão do crescimento, cujo conceito é o investimento em infraestrutura que, juntamente com medidas econômicas, estimula os setores produtivos e, ao mesmo tempo, leva benefícios sociais para as regiões do país.

O programa de aceleração do crescimento é um programa de desenvolvimento planejado para execução no período de 2007 a 2010, que visa promover a aceleração do crescimento econômico, o aumento da oferta de emprego, e, a melhoria das condições de vida da população brasileira. (PAGANI, 2009, p.215).

O PAC surgiu então como carro-chefe da campanha eleitoral de Dilma Rousseff, idéia simplificada de governo, e tem como modelo de desenvolvimento econômico e social e que combina a tentativa de crescimento da economia com a distribuição de renda para famílias necessitadas. 


\section{Monografias Ambientais}

REMOA

(Revista Eletrônica do Curso de Especialização em Educação Ambiental da UFSM)

Símbolos ou idéias únicas foram criadas para os programas de governo de ambos os candidatos, contextualizados como fins eleitorais, resumindo todos os gastos e investimentos dos candidatos sob uma nomenclatura, para facilitar a divulgação de suas campanhas eleitorais, simplificadas em programas de governo.

Em seu site Dilma afirma: "Achamos que todos os bons programas de governo foram sempre acusados de serem eleitorais. Sem sombra de dúvida, esse programa tem critérios muito explícitos, objetivos. Tem espaço para todo mundo" (ROUSSEFF, 2009).

Idéias iniciais de programas de governos são direcionadas de forma objetiva e resumidas para o público alvo.

Segundo Dominach (1955) através da idéia única essas idéias progridem sempre no sentido da maior simplificação, à palavra de ordem e da criação de slogans, breves e bem cunhados, segundo as técnicas desenvolvidas pela publicidade. E isso nos leva ao diário de Joseph Goebbels que apresenta um protótipo de teoria da propaganda:

A propaganda deve, portanto, ser sempre essencialmente simples e repetida. Afinal de contas, obterá resultados práticos, no sentido de influenciar a opinião pública, aquele que puder reduzir os problemas à sua expressão mais simples, e que tenha coragem de persistir em apresentá-las sempre na sua forma simplificada, apesar das objeções dos intelectuais. (GOEBBELS 29/1/42).

A lei de simplificação ou do Inimigo único, em linhas gerais, pode ser entendida no sentido de que a propaganda deve ser direta, simples e de fácil assimilação por qualquer espécie de público.

Assim, resumindo em uma mensagem clara e objetiva os seus propósitos, a campanha obterá resultados práticos, de modo a influenciar a opinião pública.

\section{MÉTODO DO CONTÁGIO}

Reunir diversos adversários em uma só categoria, em uma soma individualizada. Nessa lei pode-se salientar a existência da chamada oposição política e que em nosso sistema de governo, o presidencialismo, por sua vez, depara-se com este fenômeno, normal em todos os sistemas de governo, visto que a reunião dos adversários em um só e torna simples a disseminação de uma campanha política partidária.

A oposição é vista dentro da mesma ideologia, cuja visão política é a social-democracia dos dois partidos nestas campanhas.

Segundo Keane (1984) esta é uma forma de visão política que justifica novas formas de dominação burocrática, e que impede ao mesmo tempo a renovação das teorias da autonomia democrática.

De acordo com a teoria da social-democracia, a defesa da democracia é virtualmente equivalente à luta para ganhar o controle de instituições burocráticas enfraquecendo dessa maneira o poder do capital, as desigualdades e perdas de liberdade pelas quais é responsável.

Pode-se argumentar que o PSDB e o PT estão disputando a hegemonia política no Brasil, e que os partidos políticos restantes, independentemente de seu tamanho, geralmente subordinam suas ações políticas nacionais aos movimentos desses dois partidos, cabendo assim a formação de coligações partidárias e adotando a mesma oposição referente aos dois respectivos partidos dominantes. 


\section{Monografias Ambientais}

Coligação partidária é um método usado pelos partidos políticos para aumentar suas forças eleitorais. Também é uma maneira de fazer com que os partidos que têm fraca expressão eleitoral não fiquem alijados da representação. Numa eleição majoritária, apenas um candidato de um dos partidos concorre e os outros partidos que estão na coligação apoiam o candidato em questão, em troca de favores políticos. (FULGENCIO, 2007, p.242).

Os partidos políticos são desenvolvidos e implantados através do "contágio pelo exemplo", do contato e da atração pessoal. O desejo de obter satisfação faz com que a população moderna se sinta atraída pelos que aparentam possuir esta prosperidade distante.

Ainda que a realidade seja de miséria e angústia, imagens de amizade e alegria, através de pessoas felizes, saudáveis e livres são utilizadas na propaganda política, pois a eficácia é maior quando o exemplo humano é coletivo.

O candidato José Serra utilizou-se de imagens alegres para despertar esta emoção e atrair eleitores através do contágio.

No dia 13 de outubro, o programa eleitoral gratuito de Serra no meio TV e posteriormente lançado na internet, iniciou com imagens do nascimento de uma criança. Doze dias depois, o candidato salientou para o público jovem através de centros da juventude, eventos culturais e postos de internet gratuita inseridos em São Paulo. "Quero fazer um governo amigo do jovem brasileiro", disse Serra.

A manifestação de massas, comícios ou desfiles durante o período de Goebbels eram o meio de contágio mais difundido.

Assim, empregavam determinados elementos, com o objetivo de transformar a população em um único ser, como: bandeiras, que possuem efeito dominante, sobretudo se vermelhas; emblemas e insígnias que produziam um efeito de fascínio e religiosidade, por reunir as massas em um ritual; legendas reproduzindo os temas do partido em slogans; uniformes de militantes que causavam sensação de heroísmo; a música atuando na incorporação do individuo à massa, gerando uma consciência comum; e, se era noite, os projetores e tochas, que aprimoravam a fascinação e a impressão de religiosidade. Portanto, era possível estabelecer uma relação de hipnose com a multidão, dominando-a.

De acordo com Dominach (1955), na maioria das vezes, os hitleristas induziam a população ao limite extremo, a partir de processos de caráter fisiológico. As grandes manifestações começavam pela manhã, quando os primeiros assistentes chegavam ao local. Após o meio-dia, sobrevinham as delegações e instalavam-se atrás das bandas de corneteiros e de música. Aproximadamente às 19 horas, os dignitários do partido apareciam, iniciando com novos gestos um período de recolhimento e de maior expectativa. Posteriormente Goebbels e Goering chegavam, e então Hitler surgia entre grande aclamação e primeiramente realizava um contato passional com a multidão, exausta por tanto esperá-lo.

No discurso político, os oradores promovem um sentimento de cumplicidade, através da intercalação de sentenças e frases irônicas, que diminuem a tensão dos ouvintes e promovem o riso, harmonizando a multidão.

A extensão do culto à personalidade criado em torno de Hitler torna-se evidente através da introdução da saudação "Heil Hitler", uma invocação pessoal de cumprimento que elevava Hitler a níveis quase que sobrenaturais. Goebbels criou deliberadamente em torno de Hitler uma aura messiânica projetada para colocá-lo acima da política monótona do cotidiano. (REES, 1995, p.54). 


\section{Monografias Ambientais}

REMOA

(Revista Eletrônica do Curso de Especialização em Educação Ambiental da UFSM)

Os atuais candidatos á Presidência da República do Brasil também fazem uso deste método, através de comícios que reúnem as massas, nos quais são empregados símbolos como bandeiras, slogans, músicas, luzes e projetores, para que produzam um efeito de domínio sobre a população. Em um comício de Dilma Rousseff em Campinas, Lula afirmou, juntamente com a sua candidata, referindo-se aos veículos de comunicação:

Eles não se conformam que o pobre não aceita mais o tal do formador de opinião pública. Que o pobre está conseguindo enxergar com seus olhos, pensar com a sua cabeça, pensar com a própria consciência, andar com as suas pernas e falar pelas suas próprias bocas, não precisa do tal do formador de opinião pública. Nós somos a opinião pública e nós mesmos nos formamos (LULA, 2010).

Neste caso, o presidente reuniu a mídia, os jornalistas e os adversários políticos em apenas um segmento, denominando-os "eles", enquanto que as massas foram chamadas de "nós", criando um sentimento de cumplicidade e harmonia na multidão, seguido de uma impressão de unanimidade e exercendo influência através do contágio.

\section{TRANSPOSIÇÃO}

Trata-se de carregar sobre os adversários seus próprios erros e defeitos, respondendo ataque com ataque. "Se não podes negar as más notícias, invente outras que as distraiam".

De acordo com Pinho (2001), para que a propaganda tenha eficiência, é necessário explorar o ponto fraco do adversário. Assim, a melhor maneira de se responder ao adversário é colocar sua propaganda em contradição com os fatos. Se estes procederem de fontes de informação do adversário, é ainda melhor, pois será capaz de desmoronar a argumentação adversária, mesmo que relacionados a um único ponto da argumentação adversária. Para combater uma opinião, é necessário que se tenha essa mesma opinião, procurando aos poucos conduzir o adversário a conclusões diferentes daquelas que ele pretende com suas teses. (PINHO, 2001, p.152).

Para desconsiderar o adversário, são questionados fatos relacionados à vida do político em questão e que contradizem sua conduta atual, podendo ser também usados contra uma possível aliança com partidos que ideologicamente são contrários.

A propaganda política se vale de idéias e conceitos, mas os transforma em imagens e símbolos; os marcos da cultura são também incorporados ao imaginário, que é transmitido pelos meios de comunicação. A referência básica é a sedução, elemento de ordem emocional e grande eficácia na atração das massas (FREITAS E SOUZA, 1998, p. 201-202).

Da farsa à falta de idéias, juntamente com o poder da mídia, sucedem-se cenas que demonstram a escassa perspectiva de propaganda política de ambos os candidatos, o elemento "mídia" contribui com um conjunto de significados e simbologias. Os meios articulam-se com seu poder de participação e influencia dentro da sociedade brasileira. 


\section{Monografias Ambientais}

REMOA

(Revista Eletrônica do Curso de Especialização em Educação Ambiental da UFSM)

Em seu site Dilma Rousseff tenta minimizar o caso mensalão e defendeu petistas acusados de envolvimento em casos de corrupção, como o ex-ministro da Casa Civil José Dirceu, e Antonio Palocci, ex-ministro da Fazenda, ambos réus no processo do mensalão.

É uma precipitação dizer que ele [José Dirceu] fez isso ou aquilo. Nós vivemos em um país democrático. Desde a Revolução Francesa, quem prova é acusação. Não é a pessoa acusada que prova a inocência. Eu tenho grande respeito por ele, mas não está no cerne do meu governo. Ele é militante do PT e terá sempre o seu lugar dentro do PT e acatarei porque eu respeito o PT (DILMA, 2010).

Durante um comício, em Campinas, SP, desqualificando o governo anterior de FHC, e atacando a campanha de José Serra, Dilma Rousseff afirmou:

Nós queremos aquele país onde ninguém tinha chance de subir na vida? Não! Nós queremos o país construído pelo Presidente Lula. Um País que deixou seu povo relegado ao abandono não é um País sério. (DILMA, 2010).

De acordo com a Folha de São Paulo, um manifesto assinado por partidos aliados de Dilma afirmam que José Serra representa a desesperança: "É o país que não soube enfrentar efetivamente a desigualdade social e não tinha vergonha de afirmar que uma parte da população brasileira era 'inempregável'. Portanto, o Brasil do desemprego".

José Serra, no programa eleitoral televisivo do candidato à Presidência da República de 21 de agosto, atacou diretamente a adversária petista e terminou com a seguinte afirmação: "você vai ver a propaganda da candidata Dilma daqui a pouco mas realidade é outra". (SERRA, 2010).

No dia 13 de outubro, no horário eleitoral gratuito na Televisão e postado no seu site, José Serra afirmou: "Os candidatos devem ser transparentes, verdadeiros, que assumam suas posições e opiniões sem enrolar, sem mudar ao sabor dos ventos (...) essa pode ser a eleição da honestidade, de quem nunca esteve metido em escândalos" (SERRA, 2010).

Após, em sua campanha, Serra foi comparado à Dilma. O apresentador então afirmou que Serra é experiente e ocupou vários cargos, enquanto que a candidata "nunca disputou uma eleição e só chegou aqui graças ao seu padrinho político". O candidato declarou ainda que o governo precisa parar "de gastar em bobagem", "pegar pesado contra a corrupção" e investir mais em infra-estrutura para criar empregos e tornar o Brasil competitivo.

No horário eleitoral televisivo desta mesma data, Dilma comparou o governo do PT com o do PSDB. Segundo ela, Serra foi responsável pelas privatizações da Vale e da Light, durante o governo de Fernando Henrique Cardoso. Também não existiam programas de transferência de renda, salvo o Renda Cidadã, que atenderia apenas 140 mil famílias.

E mais, a candidata enfatizou que no cargo de governador de São Paulo, o candidato teria privatizado trinta e uma empresas e estabelecido a cobrança de pedágio em rodovias. Em seu site Dilma postou um vídeo. "Esta é uma diferença fundamental, no nosso governo: 28 milhões de brasileiros saíram da miséria." "No governo passado isso jamais teria acontecido" afirmou Dilma, comprometendo-se a terminar com a indigência: "assumo um compromisso no meu governo de erradicar a miséria. Nosso caminho é diferente, de valorização das empresas brasileiras" (ROUSSEFF, 2010).

Assim ambos os candidatos aproveitaram-se deste princípio, atacando seu adversário, carregando-os de erros e defeitos, utilizando de idéias, conceitos e elementos emocionais, a fim de distrair e conquistar as massas. 


\section{Monografias Ambientais}

REMOA

(Revista Eletrônica do Curso de Especialização em Educação Ambiental da UFSM)

\section{EXAGERAR E DESFIGURAR}

Converter qualquer história, por menos que seja, em ameaça grave. Um dos processos jornalísticos utilizados pela imprensa dos partidos políticos é a ampliação e o exagero das notícias, que consiste em evidenciar informações convenientes aos seus desígnios.

Para Hitler (1962[1929]), "toda propaganda deve estabelecer seu nível intelectual segundo a capacidade de compreensão dos mais obtusos dentre aqueles aos quais se dirige. Seu nível intelectual será, portanto, tanto mais baixo quanto maior a massa de homens que se procura convencer".

A propaganda requer uma expressão que possa ser compreendida pelo maior número de pessoas. Assim, é necessário ajustar e apresentar as teses defendidas por uma campanha em bloco, de maneira surpreendente, reescrevendo sua doutrina através de uma linguagem de massas.

A propaganda hitlerista serviu-se sistematicamente das notícias como de um meio de dirigir os espíritos. As "informações" importantes jamais eram comunidades em "bruto"; ao aparecerem, vinham já valorizadas, carregadas de um potencial de propaganda. (DOMENACH, 2001).

Rees (1995) salienta que o objetivo mais importante da propaganda é mitificar o líder, apresentando-o de forma idealizada. Para isso, a técnida adotada por Goebbels consistia em exagerar ou até criar as qualidades de Hitler. Assim, Hitler tornou-se o símbolo da regeneração da Alemanha, através da personificação dos valores nacionais de esperança e salvação.

$\mathrm{O}$ autor afirma ainda que a imagem de Hitler foi associada a um ídolo e comparada a um deus vivo, com características semelhantes ao seus seguidores.

Hitler foi retratado como um homem que havia sacrificado a si mesmo em benefício da nação - um homem de gostos simples, que vestia um uniforme simples, comia refeições simples e trabalhava até bem tarde da noite, simbolicamente velando pela nação. $O$ Fuhrer era mostrado como um homem que havia abdicado a vida normal em família; o seu celibato era reforçado como mais um sacrifício da sua própria felicidade pessoal em benefício da felicidade do seu povo. Seu relacionamento com Eva Braun era um segredo muito bem guardado. (REES, 1995, p.54).

Esta teoria relaciona-se com a mitificação e idealização dos candidatos à Presidência da República, comparando-os a Jesus Cristo e personificando os valores de esperança e salvação.

Durante comício da candidata Dilma Rousseff, em Garanhuns (PE), o presidente Lula comparou-a a Jesus Cristo "Essa mulher foi barbaramente torturada. Não existe nada mais grave que o ser humano possa fazer com o outro do que torturar. Vocês sabem por que Jesus Cristo foi torturado". (LULA, 2010), buscando a simpatia dos eleitores oriundos de grupos religiosos.

A campanha política de Serra, por sua vez, adotou o slogan: "Jesus é a verdade e a justiça". A utilização de um ícone cristão tem o objetivo de explorar o sentimento religioso das pessoas em benefício próprio. Portanto, esta associação resgata os mesmos valores, de salvação e esperança. 


\section{Monografias Ambientais}

REMOA

(Revista Eletrônica do Curso de Especialização em Educação Ambiental da UFSM)

VULGARIZAÇÃO

Toda propaganda deve ser popular, adaptando seu nível ao menos instruído dos indivíduos aos quais se dirija. Quanto maior a massa a convencer, menos o esforço mental a realizar. A capacidade receptiva das massas é limitada, sua compreensão escassa e elas tem grande facilidade para esquecer.

Em sua obra, Rees (1995) alega que para Hitler, as massas têm um poder de recepção limitado e compreensão medíocre, assim como esquecem rapidamente. Por isso, toda a propaganda efetiva deve ficar restrita a coisas simples, e estas devem ser representadas em fórmulas estereotipadas.

De acordo com Arendt (1989) As ideologias pressupõem sempre que uma idéia é suficiente para explicar tudo no desenvolvimento da premissa, e que nenhuma experiência ensina coisa alguma porque tudo está compreendo nesse coerente processo de dedução lógica. Corroborando tal afirmação Diehl acrescenta que:

Era preciso que se apresentasse um mundo maniqueísta, de fácil compreensão e idéias simplistas, pois essa massa deveria ser conquistada por seus 'sentimentos e não por sua capacidade de análise. Quanto mais simplista e radical a propaganda, mais seguros os resultados obtidos com ela (DIEHL, 1996, p.86).

Já de acordo com SANT'ANNA (1990), a propaganda pode ser racional, ou seja, regida pelo pensamento lógico, e atuando por argumentação. Ela pretende convencer, oferecer razões ou argumentos que levem o persuadido a assumir o ponto de vista do persuasor; ou ela pode ser emotiva, quando é regida pelo pensamento associativo, e não atua por argumentação, mas por transferência. A propaganda atua por simples contigüidade, por proximidade, por semelhança, por simultaneidade, por associação emotiva ou simbólica, pretende seduzir, atrair o receptor pelo fascínio, formando verdadeira artilharia psicológica onde se emprega tudo quanto tenha valor de choque; onde, finalmente, a idéia não conta, contanto que a palavra penetre.

O objetivo de Hitler era fazer uma propaganda popular, dirigida às massas menos favorecidas intelectualmente, transmitindo a mensagem de maneira clara e direta, devido à compreensão limitada do povo.

O publicitário deve compreender os sentimentos dos receptores e adaptar sua propaganda a pontos de vista já existentes. Rees (1995) afirma em seu livro que Goebbels adotava dois critérios principais: a mensagem deveria ser de simples compreensão e fácil repetição. Para ele, é necessário se concentrar na mensagem que a propaganda deseja transmitir, e comunicá-la às massas de maneira gráfica e coloquial, utilizando uma abordagem não intectualizada.

Em sua obra, Rees (1995) afirma que o potencial persuasivo da propaganda nos filmes publicitários foi primeiramente compreendido por Goebbels, alegando que para ser efetiva e atingir seus propósitos, a propaganda deve ser agradável, pois as pessoas poderiam ser obrigadas a assistir determinada propaganda, mas não a gostar dela.

A teoria da propaganda de Goebbels, em linhas gerais, pode ser resumida em um princípio: as massas são ignorantes, portanto a mensagem deve ser direta; portanto, a propaganda deve agradar e, para tanto, seu modelo não é a política, mas o entretenimento. Os nossos propagandistas são melhores. Dia e noite, noite após noite, estão em contato direto com as massas. (GOEBBELS). 


\section{Monografias Ambientais}

REMOA

(Revista Eletrônica do Curso de Especialização em Educação Ambiental da UFSM)

Assim, a propaganda deve ainda explorar através da psicologia os anseios da população, porque o povo é conduzido principalmente por sentimentos e não pensamentos, e a propaganda objetiva agradar as pessoas, no intuito de atingi-las emocionalmente.

Para atingir a limitada compreensão das massas, Dilma esforçou-se para traduzir os números do Programa de Aceleração do Crescimento para o cotidiano da população.

$\mathrm{Na}$ tentativa de se aproximar do público feminino, a candidata aborda o preconceito contra a mulher e discursa a respeito do "aconchego do lar" em sua plataforma de campanha virtual, o programa Minha Casa, Minha Vida, postado na internet em seu site. Portanto, a "família" é personagem constante em seus discursos.

Com o objetivo de atrair eleitores, Dilma passou a chamá-los de companheiros e companheiras, em vez de senhoras e senhores. Seu objetivo é transmitir a imagem de uma mulher competente e simpática, que, como Lula, também fala a linguagem do povo.

José Serra também adotou uma postura popular nesta campanha, explorando sua origem modesta e utilizando uma favela como cenário de sua propaganda eleitoral televisiva. $\mathrm{O}$ candidato apresentou-se ao eleitorado com o seguinte jingle: "Quando o Lula da Silva sair, é o Zé que eu quero lá, o Zé Serra eu sei que anda, é o Zé que eu quero lá."

Esta cena na favela ilustrou seu primeiro programa na televisão e foi gravada em um estúdio na zona oeste paulista, e postado no site de Serra, com o objetivo de popularizar a imagem do candidato.

Em uma eleição em que a disputa se dará pelo eleitorado de baixa renda, junto ao qual o PT de Luiz Inácio Lula da Silva e Dilma Rousseff construíram seu maior ativo eleitoral, o tucano convenceu-se de que também deveria explorar o figurino popular.

Neste sentido, Serra foi orientado a conversar mais com as pessoas na rua, de modo que seus seguranças deixavam simpatizantes aproximarem-se do tucano, que costumava por microfone de lapela para captar o bate-papo informal. Estas medidas foram tomadas para que o candidato transmitisse a imagem de um político mais acessível.

\section{ORQUESTRAÇÃO}

A propaganda deve limitar-se a um número pequeno de idéias repetidas incansavelmente, apresentando-as uma e outra vez, de diferentes perspectivas, mas sempre convergindo para o mesmo conceito, sem fissuras nem dúvidas, consiste na repetição do tema principal por todos os órgãos de propaganda, nas formas adaptadas aos diversos públicos e tão variadas quanto possível. Apresentando-as uma e outra vez, de diferentes perspectivas, mas sempre convergindo para o mesmo conceito, sem fissuras nem dúvidas.

Assim, as mensagens devem ser repetidas de maneiras diferentes, apresentando e insistindo em um tema central a partir de diversos aspectos, adaptada aos diferentes públicos e através de diversos meios de propaganda.

Segundo Hitler (1962 [1929]), as massas não se lembrarão das ideias mais simples, a menos que sejam repetidas centenas de vezes. As alterações nelas introduzidas não devem jamais prejudicar o fundo dos ensinamentos cuja difusão se propõe, mas apenas a sua forma. A palavra de ordem deve ser apresentada sob diferentes aspectos, embora sempre figurando condensada, numa fórmula invariável, à maneira de conclusão.

A propaganda deve limitar-se a pequeno número de ideias e repeti-las incansavelmente. As massas não se lembrarão das ideias mais simples, a menos que sejam repetidas 


\section{Monografias Ambientais}

REMOA

(Revista Eletrônica do Curso de Especialização em Educação Ambiental da UFSM)

centenas de vezes. As alterações nelas introduzidas não devem jamais prejudicar o fundo dos ensinamentos cuja difusão nos propomos, mas apenas a sua forma. A palavra de ordem deve ser apresentada sob diferentes aspectos, embora sempre figurando condensada , numa fórmula invariável , à maneira de conclusão. (HITLER, 1962[1929], p.54).

A qualidade fundamental da campanha publicitária de propaganda é a permanência do tema, aliado à variedade de apresentação.

Deste modo, no regime nazista a campanha anti-semita dos nazistas foi dirigida pelos jornais, responsáveis por informar e polemizar; pelas revistas, que publicavam artigos sobre a noção de raça; e pelo cinema, através da produção e filmes.

A condição fundamental de uma boa orquestração é a adequação do tom e da argumentação aos diferentes públicos. Assim, Hitler evocava o heroísmo de lutas passadas perante antigos companheiros; falava de felicidade familiar diante de camponeses, e discorria a respeito dos deveres das mães alemãs em presença de mulheres.

A Igreja Católica mantém-se porque repete a mesma coisa há dois mil anos. O Estado nacional-socialista deve agir analogamente [...] Mostrar um assunto sob um novo ângulo, sempre com o intuito de adicionar novas evidências contra seu adversário e de trazer argumentos novos para o próprio lado (GOEBBELS).

No programa eleitoral televisivo, a candidata Dilma Rousseff alardeou insistentemente que, se eleita, faria mudanças no país; ao passo que, enquanto José Serra pregava a continuidade do governo Lula da Silva.

A agência Máquina Metric analisou as propagandas transmitidas de 17 a 31 de agosto de 2010, durante o horário político noturno televisivo. De acordo com tal levantamento, nestes sete dias a propaganda de Serra repetiu somente três vezes o termo "mudar". No entanto, os termos "continuar", "aperfeiçoar", "melhorar" e "manter" foram mencionados trinta e oito vezes. A propaganda de Dilma também fez trinta e oito menções a termos de continuidade, enquanto que a palavra "mudar" foi dita setenta e cinco vezes.

O jornalista da Folha de São Paulo Fernando Rodrigues,em seu blog, fez uma análise da situação:

Mais uma contradição para o vasto hall da política brasileira: apesar de ser candidata situacionista, Dilma Rousseff (PT) destaca a palavra "mudar" em sua propaganda eleitoral. Já o candidato da oposição, José Serra (PSDB), reforça termos ligados à continuidade. (RODRIGUES, 2010).

A pesquisa também revela que, neste período, Serra mencionou o nome de Dilma 25 vezes, sendo sete vezes em 24 de agosto, quando argumentou acerca da inexperiência da candidata e oito vezes em 31 de agosto, quando fez críticas às Unidades de Pronto Atendimento 24 horas do Rio de Janeiro, ao passo que propaganda de Dilma citou Serra apenas duas vezes, em 28 e 31 de agosto, ambas para citar resultados de pesquisas eleitorais. 


\section{Monografias Ambientais}

REMOA

(Revista Eletrônica do Curso de Especialização em Educação Ambiental da UFSM)

RENOVAÇÃO

Trata-se de emitir sempre informações e argumentos novos a um ritmo tal que, quando o adversário responda, o público já esteja interessado em outra coisa.

Recordando um diálogo com Von Oven, Rees (1995) narra que as idéias devem ser expressadas de forma direcionada, representando a verdade de modo claro para as pessoas mais simples, com alguns ajustes. O pensamento ideológico arruma os fatos sob a forma de um processo absolutamente lógico, isto é, age com uma coerência que não existe em parte alguma no terreno da realidade (ARENDT, 1989).

Segundo Moreira (2002), a mídia desempenha o papel de informar e noticiar o que the é conveniente, ditando regras e moldando a conduta as pessoas. Portanto, a liberdade do indivíduo está relacionada ao poder a mídia, que o impossibilita de questionar a relevância das inúmeras informações veiculadas pela imprensa.

De acordo com Rees (1995), o jornal e o cinema, supervisionados por Goebbels, apresentavam questões da maneira mais dramática possível.

Os meios de comunicação em massa, embora em um primeiro momento sirvam para propiciar o acesso à informação, logo se mostram veículos perigosos: primeiro, por mostrarem a notícia de modo quase sempre tendencioso; segundo, por abrirem um precedente que desemboca na criação de uma sociedade alienada, incapaz de questionamento e conforma com sua posição, ainda que integrante da parcela excluída da população. (ARENDT, 1989, p. 523).

Assim, é importante transmitir rapidamente informações e argumentos novos, para que o público passa já está interessado em outra coisa no momento em que o adversário se defender das acusações. Desta forma, é possível perceber que ambos os candidatos utilizam esta técnica, emitindo sempre novas acusações contra seus adversários.

Durante o horário eleitoral televisivo da campanha para o governo de São Paulo, Lula afirmou:

É uma vergonha que o Estado mais rico, que deveria ser exemplo de politização, possa ser o retrocesso votando em alguém que nós sabemos não ter a alma do povo brasileiro, que não pensa o povo, não pensa o Brasil. (LULA, 2010).

Portanto, Lula não elenca as razões pelas quais sua candidata seria melhor do que o outro candidato, bem como não aponta as falhas do adversário. "O outro" não está na categoria das pessoas com idéias erradas, no entanto é motivo da "vergonha" que deveria sentir o eleitorado. Para Lula, só é legítimo o voto num petista.

Após, em um comício na cidade de Campinas, Lula afirmou: "Essa gente não me tolera. Mesmo lendo pesquisas de opinião pública, mesmo vendo que tem apenas $4 \%$ que acham o governo ruim e péssimo."(LULA, 2010).

Como apresentado na lei do inimigo único, trata-se de fantasiar que há uma conspiração é uma forma de manipulação. Lula utiliza-se deste método para criar novos argumentos e acusações.

Dilma também acusou Serra de ter uma visão elitista do povo, e de tentar relacionar sua imagem à do presidente Lula nestas eleições, após fazer oposição em dois mandatos. 


\section{Monografias Ambientais}

REMOA

(Revista Eletrônica do Curso de Especialização em Educação Ambiental da UFSM)

Na esteira da nova onda de violência registrada em 2010 no Rio de Janeiro, quando bandidos invadiram um hotel de luxo em São Conrado, a petista também fustigou a proposta de Serra de criar o Ministério da Segurança, alegando que a polícia tem que ser "mais eficiente e menos corrupta", criticando a divisão de secretarias que tratam do assunto em São Paulo, estado que Serra governava até se licenciar para concorrer à presidência. Segundo Dilma, em seu site, o tucano não conseguiu combater o crime organizado quando era governador e está "copiando" suas propostas.

Quem usa a imagem do presidente Lula, porque ele está com a popularidade alta, tem uma visão elitista do povo. Uma visão que acha que o povo acredita em quem foi contra Lula durante oito anos de mandato e em quem, na campanha de 2002, incentivou a teoria do medo (ROUSSEFF, 2010).

A candidata ainda observou que "Serra alfineta Lula de manhã e à tarde, discordando de tudo, e à noite aparece ao lado dele", afirmou a candidata, referindo-se à propaganda do horário eleitoral gratuito televisivo, onde o ex-governador e o presidente são apresentados como "dois homens que têm história, dois líderes experientes". No seu site Dilma afirma que:

Quem usa a imagem do presidente Lula, porque ele está com a popularidade alta, tem uma visão elitista do povo. Uma visão que acha que o povo acredita em quem foi contra Lula durante oito anos de mandato e em quem, na campanha de 2002, incentivou a teoria do medo (ROUSSEFF, 2010).

Ainda, Dilma postou uma afirmação da participação de Serra no escândalo do mensalão, que atingiu o PT em 2005.

Não acredito que o nosso povo seja ingênuo, incapaz de ter uma visão crítica. Se o povo não entendesse direitinho o que acontece, nós não teríamos conseguido fazer o governo que fizemos. Enquanto a oposição queria nos derrubar, quem nos sustentou foi o povo brasileiro (ROUSSEFF, 2010).

Em nova disputa com Serra, Dilma pediu aos jornalistas que investigassem se a experiência paulista de dividir o combate ao crime em três secretarias funcionou. Após, afirmou:

Isso não levou à derrota do crime. Uma secretaria não conversava com a outra. Não é o fato de criar um Ministério da Segurança que vai resolver. Se fosse assim, no Estado de São Paulo o crime estaria erradicado. (ROUSSEFF, 2010).

A candidata prometeu ampliar as Unidades de Polícia Pacificadora (UPP), investindo 87\% dos recursos do Ministério da Justiça em segurança pública. O candidato do PSDB à Presidência, José Serra, acusou o governo federal de financiar "blogs sujos" e realizar "patrulhamentos e perseguições sistemáticas" a jornalistas.

Boa parte desta estratégia não deixa de ser alimentada por recursos públicos, como por exemplo da TV Brasil, que não foi feita para ter audiência, mas para criar empregos na área de jornalismo e servir de instrumento de poder para um partido. (SERRA, 2010).

Serra também criticou Dilma Rousseff, e o PT por defenderem o "controle da mídia", o que significa censura e restrição à liberdade de expressão. 


\section{Monografias Ambientais}

REMOA

(Revista Eletrônica do Curso de Especialização em Educação Ambiental da UFSM)

Durante a realização de um comício em Maringá (PR), o candidato do PSDB culpou Luiz Inácio Lula da Silva pela violência ter tomado conta da campanha eleitoral. Serra ainda comentou a respeito do incidente pelo qual passou no dia anterior quando realizava uma passeata no Rio de Janeiro e foi atingido por um rolo de adesivos, em um tumulto provocado por petistas.

O PT não sabe disputar uma eleição democrática, que pressupõe encarar o concorrente como adversário, e não como inimigo. Fui agredido ontem [quarta-feira] e todo mundo que estava em volta viu que não foi nada leve. (...) Nós somos contra a violência e contra tratar adversário como o inimigo a ser destruído. Creio que, infelizmente, a atitude do presidente da República, de se jogar de corpo e alma no processo eleitoral, em vez de governar o país, e ao mesmo incitar a destruir os adversários, como ele tem feito, há vários exemplos nesse sentido, só contribui para esse clima de violência" (SERRA, 2010).

Serra acusou os adversários de profissionais da mentira e profissionais da violência. Afirmou ainda que, ao contrário de Lula, não os trata como inimigos e que quem está acirrando a campanha "é o outro lado", com uma "campanha de mentiras". Em seu site afirmou que:

Quem está acirrando a campanha o tempo inteiro é o outro lado. Primeiro, através da mentira. É a maior campanha de mentiras que eu já vi na minha vida. São os profissionais da mentira. E são também profissionais da violência. Já houve várias situações onde fizeram cerco, agressões e intimidações. De ontem (no Rio) passaram da medida, inclusive pelo tipo de gente que foi levada lá, que não são militantes tradicionais. Quer dizer, é gente de repressão, de atividade de reprimir mesmo. E o incidente comigo foi apenas um exemplo do que aconteceu ontem. Teve uma jornalista que também foi ferida porque eles agridem com violência. É gente preparada para intimidar, mas não vão nos intimidar. Nós vamos continuar nossa campanha, mas sem reproduzir o que eles fazem (SERRA, 2010).

O tucano ainda comentou a última pesquisa no lbope, que o coloca 11 pontos atrás de sua adversária Dilma Rousseff, afirmando que os institutos passaram vergonha no primeiro turno, e que também esta pesquisa é estranha.

"Os institutos passaram um vexame no primeiro turno, inclusive o lbope, foi um vexame, errou até na pesquisa de boca de urna. Aqui no Paraná foi um dos casos mais dramáticos. Houve diferenças incríveis aqui, como houve também em Santa Catarina, entre os que os institutos diziam e o que as urnas disseram. Essa pesquisa do Ibope é estranha porque não há registro dos questionários, como a legislação exige. Segundo, o resultado já tinha sido publicado antes de que a pesquisa estivesse pronta, em um blog aí bem informado, o que é muito esquisito, vazar números da própria pesquisa antes que a pesquisa esteja pronta. Seria muita coincidência que acertasse. Então, são situações esquisitas" (SERRA, 2010).

O presidente Lula chamou Serra de irresponsável por propor um salário mínimo de $\mathrm{R} \$$ 600,00 a partir do próximo ano. Serra alegou que o mínimo neste valor não é apenas uma promessa de campanha e concretizará-se no ano que vem, caso eleito, através de uma melhor de gestão do governo, diminuição dos gastos e fim da corrupção.

O fim da corrupção vai ajudar bastante para chegarmos a um salário mínimo de $\mathrm{R} \$ 600$. 0 corte de desperdícios e com a eliminação da corrupção o país poderá sim ter um salário mínimo melhor. Isso não é irresponsabilidade (SERRA, 2010). 


\section{Monografias Ambientais}

REMOA (Revista Eletrônica do Curso de Especialização em Educação Ambiental da UFSM)

Em um debate, José Serra afirmou que já foi vítima de espionagem praticada pelo PT.

O pessoal do PT faz espionagem, fez coisas gravíssimas. Isto é uma afronta à nossa Constituição, de espionar as pessoas ilegalmente. Tudo isso foi pura espionagem para poder encontrar armas eleitorais, mas não foram encontradas" (SERRA, 2010).

Então, Dilma Rousseff (PT) acusou o adversário José Serra (PSDB) de agredi-la pessoalmente. "O nível de agressão pessoal é muito alto por parte do candidato"(ROUSSEFF, 2010).

Deste modo, o princípio da Renovação foi aplicado na campanha dos dois concorrentes à Presidência da República, pois cada candidato emitiu rapidamente novas informações e argumentos.

Assim, estabeleceu-se uma sucessão de acusações com o objetivo de entreter o público com novas revelações, para que já estivesse interessado em outra notícia quando o adversário respondesse as denúncias.

\section{VEROSSIMILHANÇA}

Consiste em construir argumentos a partir de fontes diversas, através de informações fragmentárias. Este princípio utiliza de informações para Ihes atribuir uma realidade, manipulando a opinião pública através de técnicas persuasivas.

Sem dúvida, a opinião pública pode ser formada, modelada ou manipulada pela propaganda política, que é uma força poderosa e difícil de ser vista isolada dos meios de comunicação, que Ihe dão voz e vida. Entretanto, a propaganda nazista concomitantemente com o uso de técnicas de persuasão baseadas nos mais sofisticados mecanismos psicológicos - encontrou também um terreno fértil no clima de descontentamento e frustração do povo alemão, sem o qual não teria contribuído para uma modificação de opinião tão profunda e generalizada. (PINHO, 2001).

Assim, determinada questão torna-se intuitivamente verdadeira, ou seja, estabelece-se uma realidade portadora de uma aparência ou probabilidade de verdade, em uma relação ambígua entre imagem e idéia.

\footnotetext{
Nesse terreno onde política e cultura se mesclam com idéias, imagens e símbolos, definese o objeto propaganda política como um estudo de representações políticas nas sociedades contemporâneas, os meios de comunicação de massa passaram a dispor de aparatos técnicos e científicos altamente sofisticados, que permitem a fabricação e manipulação dos ideais coletivos. (FREITAS E SOUZA, 1998. p.202).
}

De acordo com Zukin (1992) e Donsbach (1995), em função das necessidades comerciais e de marketing, a mídia substituiu seu compromisso original de apresentar informação à opinião pública baseada em assuntos relevantes, pela banalização da opinião através da abordagem de tópicos marginais. Portanto, a tentativa de avançar na democratização a partir dos meios de comunicação foi abortada. Em vez do uso educativo das técnicas de sondagem política, a mídia inventa assuntos que atraiam a atenção do público e a preferência dos anunciantes, para depois divulgar resultados como se fossem eventos do mundo real, forçando sua introdução na agenda pública. Este modelo vertical de modelagem da agenda, apesar de adequar-se às necessidades políticas e comerciais da mídia, é prejudicial ao progresso da democracia. 


\section{Monografias Ambientais}

Os discursos de Hitler aos seus generais, durante a guerra,, são verdadeiros modelos de propaganda, caracterizados principalmente pelas monstruosas mentiras com que o Fuhrer entretinha seus convidados na tentativa de conquista-los (ARENDT,1989, p. 392).

Em seu diário, Goebbels utiliza a imprensa para encobrir alguns fatos que iriam contra seu movimento, enquanto dissimula outros a respeito dos judeus, a fim de disseminar o ódio contra este povo. "Quando a imprensa judaica reclama que o movimento Nacional Socialista tem a permissão de falar em todas as rádios alemãs por causa de seu chanceler, podemos responder que só estamos fazendo o que vocês sempre fizeram no passado." GOEBBELS (1942).

Nesta situação, questões para as quais não se tem argumentos devem ser encobertas e dissimuladas com a ajuda dos meios de comunicação. "Existe uma revista que não lembro o nome dela. Ela destila ódio e mentira. E eu queria pedir para você, Dilma e para você, Aloizio Mercadante: não percam o bom humor".(LULA, 2010).

Nesta afirmação, realizada durante um comício em Campinas (SP), o Presidente construiu argumentos a partir de informações fragmentárias, de que qualquer revista estaria dissimulando informações prejudiciais ao PT.

Portanto, Lula aproveitou-se deste comício em para defender sua candidata, criando uma realidade de inocência, quaisquer que fossem as acusações.

Em um comício no município de Caxias do Sul (RS), Serra utiliza de valores morais para atacar a adversária: "Os valores morais. Infelizmente essa questão acabou entrando como centro desta campanha. Porque nós temos os valores tradicionais da democracia brasileira sofrendo ataques" (SERRA, 2010).

Desta maneira, o candidato também criou argumentos a partir de informações fragmentárias, acusando a rival de atacar os seus valores tradicionais da democracia do país. Assim, a adversária foi desmoralizada através da criação de uma realidade de mau caráter, dotado de dissimulação, falta de moral e valores democráticos.

Em Goiânia, Luiz Inácio Lula da Silva e Dilma Rousseff, afirmaram que os adversários não possuem caráter, promovendo mentiras e campanhas para converter o Brasil em um país de ódio. Lula pediu voto para Dilma e alegou que é preciso escolher entre um projeto para o futuro ou do passado. "Não podemos esquecer o Brasil que recebemos deles em 2003: o Brasil da privatização, do FMI, do desemprego, da desesperança, da falta de oportunidade." Dilma disse que o adversário adotou uma campanha de falsidades e mentiras, pois teme ser derrotado. Segundo ela, os concorrentes não são generosos com a população. "Criaram uma campanha de ódio, tentando criar uma coisa que o Brasil jamais permitiu, porque somos o país da convivência. Árabes e judeus sentam-se na mesma mesa e não guerreiam. Católicos, evangélicos e espíritas convivem de forma fraterna nas mesmas escolas. Não podemos deixar que nos transformem num país cheio de ódio", disse a petista.

Durante um discurso para empresários em Goiás, o candidato José Serra também acusou o PT de mentir na campanha eleitoral. Em referência aos adversários, o candidato alegou que a campanha transformou-se em "mentira, teatro e em processar vítimas". "O PT espalhou que eu vou privatizar os Correios, a Caixa, o Banco do Brasil e proibir concurso no Brasil. É tudo o que eu defendo. Campanha não é debate, é mentira, é teatro, é processar vítima. Tudo como máquina de intimidação. Basta olhar o programa de direitos humanos do governo, o programa aprovado pelo PT e a versão apresentada à Justiça Eleitoral", afirmou. 


\title{
Monografias Ambientais
}

REMOA

(Revista Eletrônica do Curso de Especialização em Educação Ambiental da UFSM)

\section{SILENCIAÇÃO}

Encobrir as questões sobre as quais não tenha argumentos e dissimular as notícias que favorecem o adversário, contraprogramando com a ajuda dos meios de comunicação afins.

\begin{abstract}
A combinação de técnicas de relações públicas com base no aspecto psicológico e as transmissões em massa por meio da comunicação eletrônica resultaram na propaganda política moderna. A razão foi deslocada não apenas pela substituição da imprensa pelas transmissões eletrônicas, mas também pela ciência das relações públicas como a linguagem principal por meio da qual a comunicação ocorre no foro público - tanto por motivos comerciais como políticos (GORE, 2007, p. 85).
\end{abstract}

A propaganda política desencadeia uma luta de forças simbólicas, que visa ao reforço da dominação, ao consentimento em relaçãoao poder e à interiorização das normas e valores impostos através das mensagens propagandísticas (Freitas e Souza, 1998, p. 202).

José Serra acusou, indiretamente, a rival de mentir por ter atenuado sua posição a respeito da liberação do aborto. Em um vídeo que circula na internet, Dilma mostra-se favorável à prática, o que afetou sua votação entre religiosos católicos e evangélicos, de acordo com analistas.

Neste sentido, o ex-governador de São Paulo afirmou: “O que está em questão agora nesta campanha não é se é contra ou a favor. É a mentira. De repente, diz que é contra por motivos eleitorais. Isso é o que eu acho que está errado. A questão é dizer a verdade". (SERRA, 2010).

Serra também criou argumentos a partir de informações que conferiam a adversária um mau caráter, que estaria disfarçado por questões eleitorais, apresentando-a como uma pessoa dissimulada, mentirosa e desonesta.

Em 02 de setembro, na cidade de Porto Alegre, Dilma Rousseff, fez fortes ataques contra o adversário José Serra, e também anunciou que entrará pessoalmente com uma representação judicial contra Serra por divulgação de crime por fato inverídico: “A campanha do adversário e o partido dele estão desesperados (...) É importante perceber que no processo democrático se pode até perder a eleição, mas não se pode perder a dignidade" (ROUSSEFF, 2010).

Assim como o adversário, Dilma fez uso dos meios de comunicação para encobrir questões acerca das quais não possuía argumentos, e dissimulou notícias que desfavoreceram o candidato.

\section{TRANSFUSÃO}

A propaganda sempre opera a partir de um substrato preexistente, seja uma mitologia nacional, ou um complexo de ódios e preconceitos tradicionais. Trata de difundir argumentos que possam arraigar-se em atitudes primitivas.

A propaganda sempre opera a partir de um substrato preexistente, seja uma mitologia nacional, ou um complexo de ódios e preconceitos tradicionais.

Trata-se de identificar e explorar o sentimento popular em proveito próprio, através da manipulação da opinião pública a partir de crenças pré-existentes. A propaganda apreende e explora sentimentos conscientes ou inconscientes da alma dos povos.

Inicialmente, o orador não deve contradizer a multidão, declarando-se de acordo e acompanhando-a, para que após seja possível adequá-la ao objetivo visado. A população tende a harmonizar-se com os seus semelhantes, em uma relação de concordância. A conformidade geral de opiniões é utilizada como veículo de entusiasmo e de terror. 


\section{Monografias Ambientais}

REMOA

(Revista Eletrônica do Curso de Especialização em Educação Ambiental da UFSM)

Para conquistar o assentimento e causar a impressão de unanimidade, os partidos muitas vezes fazem uso de manifestações e desfiles de massas.

Os argumentos do orador são trabalhados de acordo com os objetivos da propaganda política. Para promovê-la, são utilizados elementos capazes de transformar a multidão em um único ser, como bandeiras ou estandartes, emblemas ou insígnias, inscrições e legendas, uniformes, música, projetores e tochas, saudações e vivas, e minutos de silêncio.

O chefe político apela imediatamente para o sentimento preponderante da multidão (...). O que conta é prender, pela palavra e por associações sentimentais, o programa proposto, à atitude primitiva que se manifestou na multidão (LIPPMAN, 1997).

Em sua campanha, Dilma repetiu vários slogans que afirmavam a necessidade de dar continuidade ao processo de mudança do Brasil e defendeu o estabelecimento de uma relação afetiva com o povo. Nas campanhas de rádio, o tom sentimental também foi abordado, com anúncios ao som de música sertaneja e com elogios ao Lula.

Em vez do slogan oficial da campanha, o jingle da candidata na rádio afirma: "Deixo em suas mãos meu povo e tudo o que mais amei, mas só deixo porque sei que vai continuar o que fiz e meu país será melhor e meu povo mais feliz, do modo que sempre quis".

O candidato José Serra, na propaganda televisiva, também apelou para o sentimentalismo e emoção. Ele aparece em cenas que remetem à esperança, visitando bairros pobres, abraçando idosos e beijando na testa uma mulher doente, para garantir que histórias de superação o emocionam e lhe dão forças para lutar.

Durante a disputa, os adversários também utilizam de questões polêmicas para acusar uns aos outros e assim despertar os sentimentos das massas. A campanha de Dilma ainda acusou o concorrente de instigar o ódio e dividir o país, ao conduzir discussões a respeito do aborto e assuntos polêmicos para os religiosos.

O Brasil de Dilma, assim como o de Lula, é e será uma terra de liberdade, onde todos poderão, sem qualquer tipo de censura, expressar suas idéias e convicções. (...) Queremos um Brasil unido em sua diversidade política, étnica, cultural e religiosa(...) Repudiamos aqueles que querem explorar cinicamente a religiosidade do povo brasileiro para fins eleitorais. (...) Tentar introduzir o ódio entre as comunidades religiosas é um crime. (...) Não permitiremos que nos tentem dividir. (ROUSSEFF, 2010).

Serra declarou que Dilma, inicialmente a favor da prática do aborto, de mudar de opinião sobre a questão para agradar aos eleitores. Em um comício no Rio de Janeiro, a mulher do candidato acusou a adversária do PT de ser a favor do aborto e de matar criancinhas. $\mathrm{O}$ candidato do PSDB se posicionou contra o procedimento, alegando razões religiosas e pessoais.

O que está em questão nesta campanha não é apenas ser contra ou a favor. É a mentira. Quem é a favor, de repente, diz que é contra por motivos eleitorais. Acho errado. (...) Eu não tenho duas posições, uma pessoal e uma eleitoral. Minha posição na vida pública e na pessoal se entrelaçam. Eu não fico mudando de opinião segundo o vento do eleitorado (SERRA, 2010). 


\section{Monografias Ambientais}

REMOA

(Revista Eletrônica do Curso de Especialização em Educação Ambiental da UFSM)

UNANIMIDADE

Significa convencer a muita gente de que pensa "como todo mundo", criando uma (falsa) impressão de unanimidade.

Este princípio relaciona-se com a tentativa de reforçar ou criar, mesmo artificialmente, unanimidades, a fim de conseguir apoio através do contágio. A maior parte das pessoas tende a harmonizar-se com os seus semelhantes, sem emitir idéias contrárias e mantendo a concordância.

Desta forma, inúmeras opiniões podem ser traduzidas como conformismo, e se mantêm devido a impressão de que a opinião de cada indivíduo é a expressada unanimemente. Portanto, a propaganda deve criar a impressão de unanimidade.

A impressão de que existe uma conformidade geral de opiniões é uma técnica adotada pelos regimes totalitários para produzir entusiasmo e terror. De acordo com Dominach, dificilmente algum espectador permanecia indiferente ou hostil à Hitler. Vários homens marchando ordenadamente, disciplinados e uniformizados, gera na multidão um eficaz efeito de poder.

Também os partidos políticos muitas vezes recorrem a manifestações e desfiles de massas, com o objetivo de atrair aceitação e estabelecer uma idéia de unanimidade.

Assim, através dos sentimentos de exaltação e receio difundido, o indivíduo é incitado a seguir os ideais políticos compartilhados por todos os cidadãos e o número de manifestantes adquire maiores proporções.

Neste sentido, os partidos políticos recorrem os freqüentemente a manifestações e desfiles de massas, desfiles ou comícios. Quando a massa popular desfila em uma avenida portando inúmeras bandeiras, entre ruídos de cantos, são raros os espectadores que permanecem indiferentes à manifestação. Consequentemente, os adversários optam por afastar-se, a fim de não sucumbir à fascinação momentânea.

Ainda, a presença dos partidários revela a força e a superioridade dos adversários sobre os adeptos. Portanto, a criação de uma atmosfera de força a partir do uso de símbolos, insígnias, bandeiras, uniformes e cantos manifesta um grande poder.

As pesquisas de opinião também desempenham este papel, distorcendo o espírito de representação das instituições democráticas e tornando trivial o papel das eleições. Ao promover preferências cidadãs e reproduzir uma impressão de unanimidade, exercem influência através do contágio. Para Lipmann (2007), o público permanece ausente na elaboração de opiniões genuínas e com conseqüências políticas. Portanto, as pesquisas estão sujeitas à manipulação pelas elites.

Mais recentemente, em especial em períodos pré-eleitorais, multiplicaram-se as acusações contra pesquisas publicadas sob o argumento que as mesmas estariam influenciando os votantes. Também muito freqüentemente, ocorreram denúncias contra o uso especulativo de pesquisas encomendadas por agentes de bolsa e políticos, para benefício privado, resultante de restrições legais de difusão pública dos resultados (WORCESTER, 1993).

A propaganda veiculada durante o horário eleitoral da petista Dilma Rousseff, na data de 24 de agosto, citou a pesquisa Datafolha, mostrando que Dilma estava 17 pontos à frente de Serra, com $47 \%$ das intenções de votos na disputa presidencial, enquanto o candidato do PSDB contava com $30 \%$. 


\section{Monografias Ambientais}

REMOA

(Revista Eletrônica do Curso de Especialização em Educação Ambiental da UFSM)

Segundo a Folha de São Paulo, a propaganda foi suspensa pela Ministra do Tribunal Superior Eleitoral, Nancy Andrighi, pois não exibiu todas as informações exigidas pela legislação eleitoral.

$\mathrm{Na}$ divulgação de pesquisas no horário eleitoral gratuito devem ser informados, com clareza, o período de sua realização e a margem de erro, não sendo obrigatória a menção aos concorrentes, desde que o modo de apresentação dos resultados não induza o eleitor a erro quanto ao desempenho do candidato em relação aos demais (ANDRIGHI, 2010).

Em Pernambuco, três dias antes da realização do segundo turno eleitoral, José Serra declarou à Rádio Jornal que determinadas pesquisas de intenção de voto são "alugadas", e que não é influenciado pelos resultados, admitindo o histórico errôneo de pesquisas: "As pesquisas estão muito furadas nesta eleição. Há um abuso nas pesquisas. Para o futuro, isso precisa ser examinado (...) Conheço os erros históricos das pesquisas" (SERRA, 2010).

\section{CONSIDERAÇÕES FINAIS}

No decorrer deste trabalho, podemos ver como as idéias ou princípios utilizados pela propaganda em uma população podem realmente influenciar a eleição de candidatos a cargos políticos.

Notamos também que, como à época de Hitler, nos dias de hoje a ética na política tem sido deixada de lado por algumas personalidades que, numa busca obcecada pelo "poder", não usam de moral em certas ações. Sua principal arma é baseada na proposição de que as mentiras incessantemente repetidas terminam sendo aceitas como verdade. Para tais pessoas, tantos acontecimentos criados por eles são tão repetidos que exercem sobre o povo um convencimento, que se confunde a tal ponto com a verdade que é possível relembramos a célebre frase de Goebbels "uma mentira contada mil vezes se torna realidade".

Também os estereótipos, os clichês e os chavões alimentam-se dessa facilidade da repetição, que retira o sujeito da ação e apaga a necessidade do pensar, que retira a intervenção do próprio povo a quem caberia refletir sobre as idéias e os fatos apresentados pelos candidatos, sejam eles Dilma Rousseff e José Serra ou outros quaisquer, e acabam por ser meros discursos baseados em leis e princípios de dominação pela propaganda.

E finalmente, importante destacar as leis e princípios referente à criação de Josef Goebbels, uma pessoa desaparecida e desacreditada. Podemos notar que, quanto mais pesquisamos trabalhos dos chamados "comunicadores" contemporâneos, mais, em vários aspectos, notamos a presença de Goebbels como precursor de seu trabalho.

Portanto, tanto o passado legitima o presente, que a propaganda política utilizada pelas leis e princípios de Joseph Goebbels perpetua-se até hoje no discurso político, de candidatos como Dilma Rousseff e José Serra, mesmo no ciberspaço. 


\section{Monografias Ambientais}

REMOA

(Revista Eletrônica do Curso de Especialização em Educação Ambiental da UFSM)

\section{REFERÊNCIAS BIBLIOGRÁFICAS}

<http://www1.folha.uol.com.br/especial/2010/eleicoes> Acesso em 31 de outubro de 2010.

ALDÉ, Alessandra. A construção da política: democracia, cidadania e meios de comunicação de massa. Rio de Janeiro: FGV, 2004.

ARENT, Hannah. Origens do totalitarismo. São Paulo: Companhia das letras. 1989.

AZAMBUJA, Darcy. Introdução à Ciência Política. São Paulo: Globo, 1999.

BARDIN, Laurence. Análise de conteúdo. Trad. Luís Antero Reto e Augusto Pinheiro. Lisboa: Edições 70, 2002.

BORTULUCCE, Vanessa Beatriz. Arte dos Regimes Totalitários do Século XX: Rússia e Alemanha. São Paulo: Annablume, 2008.

CARDOSO, Fernando Henrique. A Arte da Política - A História que Vivi. Rio de Janeiro: Record, 2006.

CARDOSO, Gustavo Alberto Leitão Seabra. A mídia na sociedade em rede. Rio de Janeiro: FGV. 2007.

CASTELLS, Manuel. A galáxia da internet: reflexões sobre a internet, os negócios e a sociedade. Rio de Janeiro: JZE, 2003.

CHARAUDEAU, Patrick. Linguagem e discurso: modos de organização. São Paulo: Contexto, 2008.

comunicação. São Paulo: Senac-SP, 2003.

CONEGLIAN, Olivar. Propaganda Eleitoral - De acordo com o Código Eleitoral e com a lei 9.504/97. Curitiba: Juruá, 2010.

COUTO, Sérgio Pereira. Dossiê Hitler. São Paulo: Universo dos Livros, 2007.

DIEHL, Paula. Propaganda e persuasão na Alemanha Nazista. São Paulo: Annablume, 1996.

DIZARD, Jr; WILSON, Jorge; QUEIROGA, Tony. A nova mídia. Rio de Janeiro: Jorge Zahar Editor Ltda. 1998.

DOMENACH, J. M. A propaganda política. São Paulo: Difel, 1955.

DONSBACH, Wolfgang. The role of polls in a Democracy. Wapor Newsletter. 1995.

DUARTE, Jorge; BARROS Antônio. (org.). Métodos e Técnicas de Pesquisa em Comunicação. São Paulo: Atlas, 2005.

FERREIRA, Dina Maria Martins. Não pense, veja: o espetáculo da linguagem no palco do Fome Zero. São Paulo: Annablume. 2006.

FILHO, João Freire; HERSCHMANN, Micael. Novos rumos da cultura da mídia: indústrias, produtos, audiências. Rio de Janeiro: Mauad. 2007.

FIORIN, José Luiz. Elementos de análise do discurso. São Paulo: Contexto, 1989.

FOLHA DE SÃO PAULO. disponível em:

FRANCO, Alberto Silva. Crimes Hediondos. São Paulo: Revista dos tribunais. 2005.

FREITAS, Marcos Cezar de; SOUZA, Laura De Mello. Historiografía brasileira em perspectiva. São Paulo: Contexto. 1998.

FULGENCIO, Paulo Cesar. Glossário Vade Mecum. Rio de Janeiro: Mauad. 2007.

GIBSON, Willian. Neuromancer. New York: Ace Books. 1984.

GIL, Antonio Carlos. Como elaborar um projeto de pesquisa. São Paulo: Atlas, 2002.

GLOBO.COM. disponível em: <http://g1.globo.com/tecnologia/noticia/2010/06/orkut-segue-lider-no-brasil-twitter-e- 


\section{Monografias Ambientais}

REMOA

(Revista Eletrônica do Curso de Especialização em Educação Ambiental da UFSM)

facebook-empatam.html> Acesso em: 01 de Agosto de 2010.

GOLIN, Cida.; ABREU, João Batista. Batalha sonora: o radio e a Segunda Guerra Mundial. Porto Alegre: Edipucrs, 2006.

GOMES, Neusa Demartini. Formas persuasivas de comunicação política: propaganda política e publicidade eleitoral. Porto Alegre: Edipucrs, 2004.

GORE, Alberto. O Ataque a Razão. São Paulo: Manole, 2007.

HITLER, Adolf. Minha luta. São Paulo: Mestre Jou, 1962.[1929].

HOURDAKIS, Antoine. Aristóteles e a Educação. Trad. Luiz Paulo Rouanet. São Paulo: Loyola, 2001.

http://www.midia.madriproducoes.com.br/convergencia/. Acesso em: 18 de novembro de 2010.

ITEN, Marco; KOBAYASHI, Sérgio. Eleição: vença a sua! As boas técnicas do marketing político. São Paulo: Ateliê Editorial, 2002.

JENKINS, Henry. Cultura da convergência. São Paulo: Aleph, 2008.

KEANE, John. Public Life and Late Capitalism. Cambridge: Cambridge University Press. 1984.

KUNTZ, Ronald A. Marketing Político: Manual de campanha eleitoral. São Paulo: Global, 2004.

LÉVY, Pierre. Cibercultura. São Paulo: 34, 1999.

LIPPMANN, Walter. Public Opinion. New York: Free Press Paperbacks, 1997.

LIPPMANN, Walter. The Phantom Public. New Jersey: Transaction Publishers, 2007.

MANHANELLI, Carlos Augusto. Marketing pós-eleitoral: técnicas de marketing para um mandato de sucesso. São Paulo: Summus, 2004.

MANVELL, R. e FRAENKEL, H. Goebbels. Lisboa: Aster. 1967.

MARTINS, Zeca. Propaganda é Isso aí. São Paulo: Futura, 2002.

MERCADO, Luis Paulo Leopoldo (org.). Práticas de formação de professores. Maceió: UFAL, 2008.

MICHEL, Maria Helena. Metodologia e pesquisa científica em ciências sociais. São Paulo: Atlas, 2005.

MOREIRA, Elizabeth Huber. A mídia e o exercício do poder na atualidade. Santa Cruz o Sul: EDUNISC, 2002.

NETO, Angelo Franzão. Midialização: o poder da mídia. São Paulo: Nobel. 2006.

OLIVEIRA, Lucio Sergio Porto. Informação ou propaganda? O que recebemos? 0 que percebemos? Brasília: Thesaurus, 1996.

PAGANI, Elaine Adelina. O direito de propriedade e o direito a moradia. Porto Alegre: Edipucrs. 2009.

PAULA, Camila; ANDRÉ, Aline; TAVARES, Caroline. (2009). Survirvor e Intodução. Postado no blog dos estudantes da PUC/SP. Disponível em:

PEROSA, Lílian Maria F. de Lima. A hora do clique: análise do programa de rádio "Voz do Brasil" da Velha à Nova República. São Paulo: Annablume, 1995.

PINHO, José Benedito. Comunicação em marketing: princípios da comunicação mercadológica. Campinas: Papirus. 2001.

QUEIROZ, Adolpho. Na arena do marketing político: ideologia e propaganda nas campanhas presidenciais brasileiras. São Paulo: Summus, 2006.

QUERIDO, Paulo; ENE, Luís. Blogs: Sociedade da informação. Cidade do Porto/Portugal: Centro Atlântico, 2003. 


\section{MAFALDO \& MORAES, vol.(3), n³, p. 434- 467, 2011. Monografias Ambientais}

REMOA

(Revista Eletrônica do Curso de Especialização em Educação Ambiental da UFSM)

REES, Laurence. Vende-se política. Rio de Janeiro: Revan, 1995.

REGO, Francisco Gaudêncio do. Marketing político e governamental: um roteiro para campanhas políticas e estratégias de comunicação. São Paulo: Summus, 1985.

RODRIGUES, Fernando. Disponível em <http://uolpolitica.blog.uol.com.br> Acesso em 01 de agosto de 2010.

SAAD CORRÊA, E. Estratégias para a mídia digital, internet, informação e

SANT'ANNA, Armando. Propaganda: Teoria, técnica e pratica. São Paulo: Thompson Pioneira, 2002.

SILVA, M. Sala de aula interativa. Rio de Janeiro: Quartet, 2000.

SOUZA, Marquilandes Borges de. Rádio e propaganda política: Brasil e México sob a mira Norte-Americana durante a Segunda Guerra. São Paulo: Annablume, 2004.

TORQUATO, Gaudêncio. Tratado de Comunicação Organizacional e Política. São Paulo: Thomson, 2004.

VERGARA, Sylvia Constant. Projetos e relatórios de pesquisa em administração. São Paulo: Atlas, 2003.

WACHOWICZ, Marcos. Direito da propriedade intelectual: estudos em homenagem ao Pe. Bruno Jorge Hammes. São Paulo: Jurua, 2006.

WORCESTER, Robert. Interview. El Mercurio, 1993.

ZUKIN, Cliff. Comment on syaDavis: Yes, but... public opinion is a top-down process. Public Opinion Quarterly. 1992. 